\title{
Fluoro-Substituted Metal Phthalocyanines for Active Layers of Chemical Sensors
}

\author{
Darya Klyamer (D), Dmitry Bonegardt and Tamara Basova *(D) \\ Nikolaev Institute of Inorganic Chemistry SB RAS, 3 Lavrentiev Pr., 630090 Novosibirsk, Russia; \\ klyamer@niic.nsc.ru (D.K.); bonegardt@niic.nsc.ru (D.B.) \\ * Correspondence: basova@niic.nsc.ru; Tel.: +73-833-309556
}

Citation: Klyamer, D.; Bonegardt, D.; Basova, T. Fluoro-Substituted Metal Phthalocyanines for Active Layers of Chemical Sensors. Chemosensors 2021, 9, 133. https://doi.org/10.3390/ chemosensors 9060133

Academic Editor: Ali Othman

Received: 30 April 2021

Accepted: 4 June 2021

Published: 8 June 2021

Publisher's Note: MDPI stays neutral with regard to jurisdictional claims in published maps and institutional affiliations.

Copyright: (c) 2021 by the authors. Licensee MDPI, Basel, Switzerland. This article is an open access article distributed under the terms and conditions of the Creative Commons Attribution (CC BY) license (https:// creativecommons.org/licenses/by/ $4.0 /)$.

\begin{abstract}
Metal phthalocyanines bearing electron-withdrawing fluorine substituents were synthesized a long time ago, but interest in the study of their films has emerged in recent decades. This is due to the fact that, unlike unsubstituted phthalocyanines, films of some fluorinated phthalocyanines exhibit the properties of n-type semiconductors, which makes them promising candidates for application in ambipolar transistors. Apart from this, it was shown that the introduction of fluorine substituents led to an increase in the sensitivity of phthalocyanine films to reducing gases. This review analyzes the state of research over the last fifteen years in the field of applications of fluoro-substituted metal phthalocyanines as active layers of gas sensors, with a primary focus on chemiresistive ones. The active layers on the basis of phthalocyanines with fluorine and fluorine-containing substituents of optical and quartz crystal microbalance sensors are also considered. Attention is paid to the analysis of the effect of molecular structure (central metal, number and type of fluorine substituent etc.) on sensor properties of fluorinated phthalocyanine films.
\end{abstract}

Keywords: metal phthalocyanines; fluoro-substituents; chemiresistive sensors; optical sensors; quartz crystal microbalance; thin films

\section{Introduction}

Metal phthalocyanines (MPc) belong to the class of coordination compounds with organic ligands. The phthalocyanine molecule consists of four isoindole fragments connected through nitrogen atoms of the tetrabenzoporphyrazine macrocycle. Since their discovery, phthalocyanines have been widely used not only as dyes and catalysts [1-3], but also in advanced technological fields, for example, as active layers of solar cells [4,5], diodes [6,7], and transistors [8,9]. Due to their ability to change conductivity during adsorption of various gases the application of metal phthalocyanines as sensing layers of chemiresistive sensors is of particular interest [10-12]. On the one hand, phthalocyanine macrocycles can chelate with almost all metals of the periodic table. On the other hand, various types of substituents can be introduced into their macroring [13-16]. Due to such versatility in their structure, they exhibit different sensitivity to a number of analytes.

Metal phthalocyanines bearing electron-withdrawing fluorine substituents were synthesized a long time ago [17], but interest in the study of their films has emerged in recent decades. This is due to the fact that, in contrast to unsubstituted phthalocyanines, the films of some fluorinated phthalocyanines exhibit the properties of n-type semiconductors, which makes them promising candidates for application in ambipolar transistors [18-20]. Apart from this, it was shown that the introduction of fluorine substituents led to an increase in the sensitivity of their films to reducing gases [21,22].

Another important property of metal phthalocyanines, which makes them useful for the modification of electrodes of electrochemical sensors, is their electrocatalytic and electron mediator capability [23-26]. Electrodes modified with metal phthalocyanines or their composite materials were shown to be used in amperometric, potentiometric and biosensors as well as voltammetric electronic tongues for the detection of various analytes, 
among them dopamine, glucose, cysteine and so on $[27,28]$. Among the wide variety of phthalocyanines, fluorinated derivatives occupy a special place due to the influence of fluoro-substituents on the redox potential of compounds and intermolecular interaction with analytes.

Fluorinated porphyrinoids have been the subject of several reviews over the past few years. The synthesis of fluorinated porphyrinoids and some aspects of their application for the creation of new photonic materials have been the subject of several reviews $[17,29,30]$. In a book chapter written by P. Stuzhin [17], an overview of different methods of synthesis of phthalocyanines, subphthalocyanines and porphyrazines bearing fluorine atoms and/or perfluorinated alkyl or aryl groups was provided. S. Casa and M. Henary published another critical review [30], which covers the aspects of synthesis and the application of selected fluorine-containing fluorophores. Among other fluorine-containing molecules, the authors analyzed the methods of synthesis of metal phthalocyanines bearing fluoroalkyl and fluoroaryl moieties and their application as photosensitizers for photodynamic therapy. The mini review written by Gorun et al. [31] summarizes recent researches of fluoroalkylsubstituted metal phthalocyanines, in which the majority of $\mathrm{C}-\mathrm{H}$ bonds are replaced by a combination of fluoro- and perfluoroalkyl groups as bioinspired catalytic materials. A review article written by Dinesh K. Bhupathiraju et al. [29] was focused on the reactions of nucleophilic substitution of fluorinated analogues of porphyrins, phthalocyanines, chlorin, phenylcorrole and bacteriochlorins. The authors also considered their electrocatalytic and light-absorbing properties important for various biomedical applications as well as sensing behavior. However most of the presented data in this field of chemical sensors were devoted to the use of porphyrin derivatives as fluorescence sensors for the detection of dissolved oxygen, and only very limited examples of the application of fluoro-substituted phthalocyanines in other types of sensors were given. Apart from this, questions concerning the effect of the number and type of fluorine or fluorine-containing substituents on the sensor performance were not sufficiently answered.

This review analyzes the state of research over the last fifteen years in the field of applications of fluoro-substituted metal phthalocyanines as active layers of gas sensors, with a primary focus on the sensors with electrical response (Scheme 1). Attention will be paid to the analysis of the effect of molecular structure (central metal, number and type of fluorine substituent etc.) on sensor properties of the films of fluorinated phthalocyanines.

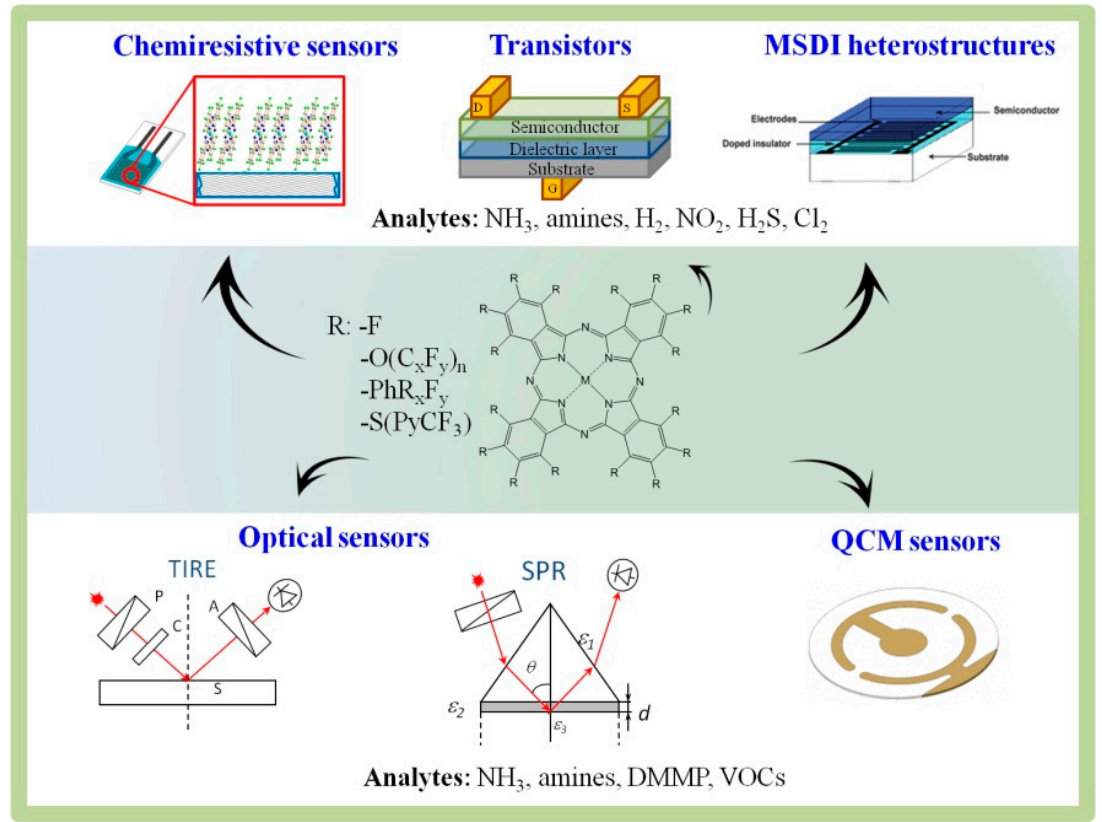

Scheme 1. Schematic representation of the application of fluoro-substituted metal phthalocyanines as active layers of gas sensors. 


\section{Brief Overview of Fluorinated Phthalocyanines and Preparation of Their Thin Films}

A large variety of phthalocyanines with fluorine and/or fluorine-containing substituents has been synthesized and investigated [32-35]. In this section, we consider only those fluoro-substituted phthalocyanines, which were used for the preparation of active layers of chemical sensors in the publications analyzed in this review. The literature analysis shows that both phthalocyanines with fluorine atoms directly in the aromatic rings and phthalocyanines bearing fluoroalkyl and fluoroaryl substituents are widely used for the preparation of active layers of gas sensors. Some example of such fluorinated MPc derivatives are summarized in Table 1 . The methods of their synthesis have already been discussed in detail in recent reviews $[17,30]$.

Table 1. Structures of fluoro-substituted phthalocyanines.

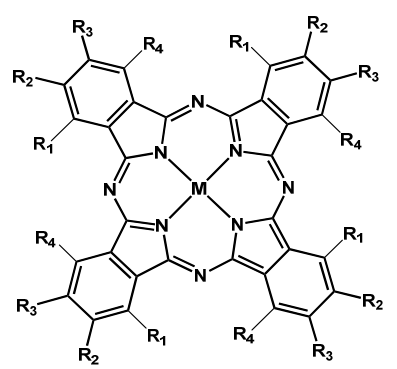

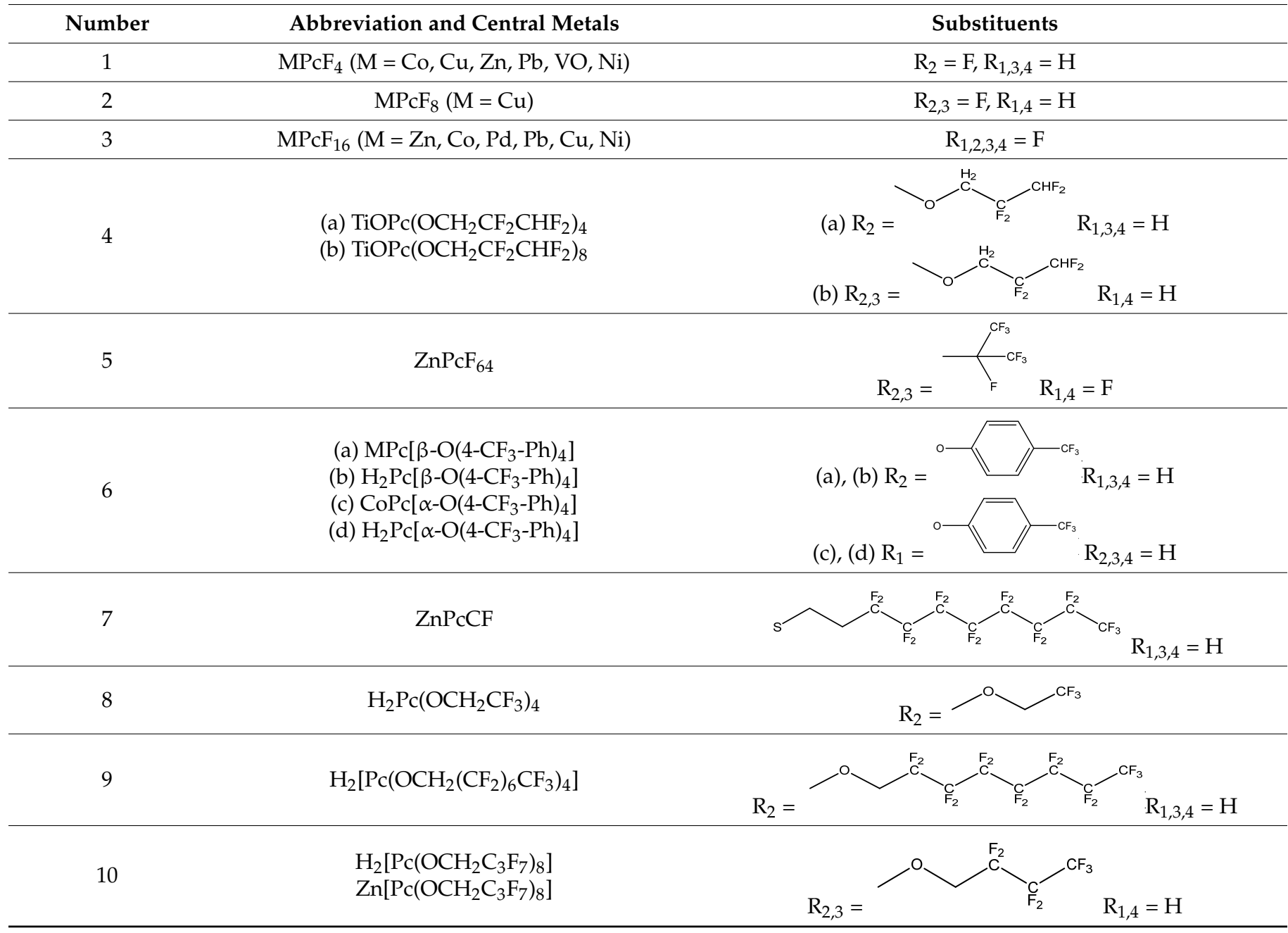


Table 1. Cont.

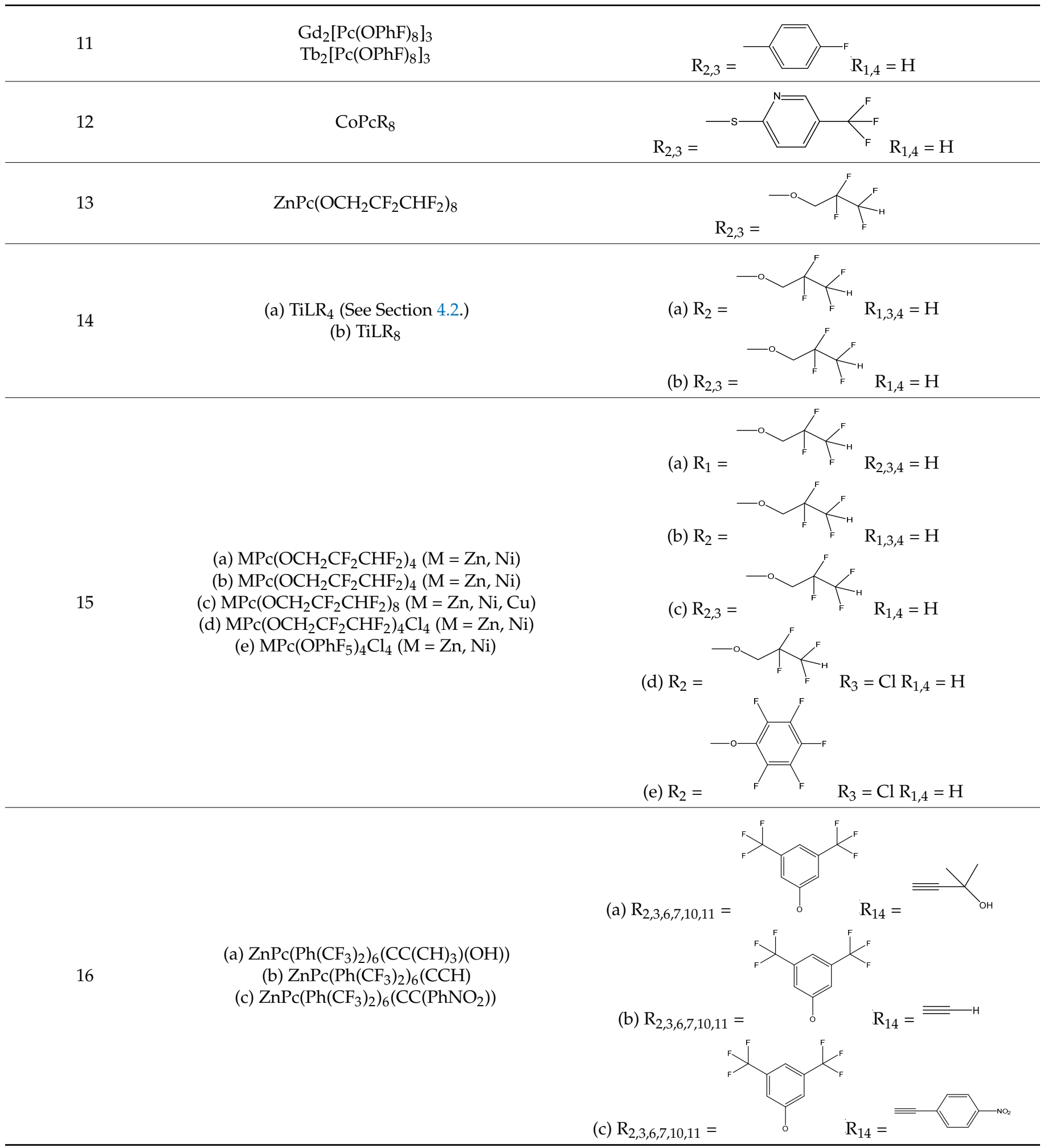

For the use of phthalocyanines as active layers of chemical sensors, it is important that a phthalocyanine is deposited as a thin film with a controlled structure and morphology on the surface of an electrode. The method of deposition of films is determined by the properties of the compound itself. It is known that phthalocyanines with F-substituents directly in the aromatic rings (Compounds 1-3, Table 1) are insoluble in 
common organic solvents, but can be sublimed in vacuum with the formation of smooth and homogeneous films $[21,32,36]$.

Thin films of $\mathrm{MPcF}_{\mathrm{x}}(\mathrm{x}=4,8,16)$ deposited by physical vapor deposition (PVD) or organic molecular beam deposition techniques are usually polycrystalline and have preferable orientation of polycrystallites relative to the substrate surface (Figure 1a-c) [37]. Their orientation degree and size of crystallites are dependent on the substrate material and deposition conditions [22,38,39], that is, the rate of film growth and substrate temperature [40]. In turn, the structure and surface morphology of fluorinated phthalocyanine films have a significant effect on their conductivity, charge carrier mobility, and sensor performance [41-43]. Summarizing the data on the deposition of films of fluorinated metal phthalocyanines given in the literature, the main conditions of these processes can be identified. The films are deposited in ultra-high $\left(\sim 10^{-9}\right.$ Torr $)$ or high vacuum $\left(\sim 10^{-5}-10^{-6}\right.$ Torr $)$ at evaporator temperatures from 300 to $480{ }^{\circ} \mathrm{C}$ [38].
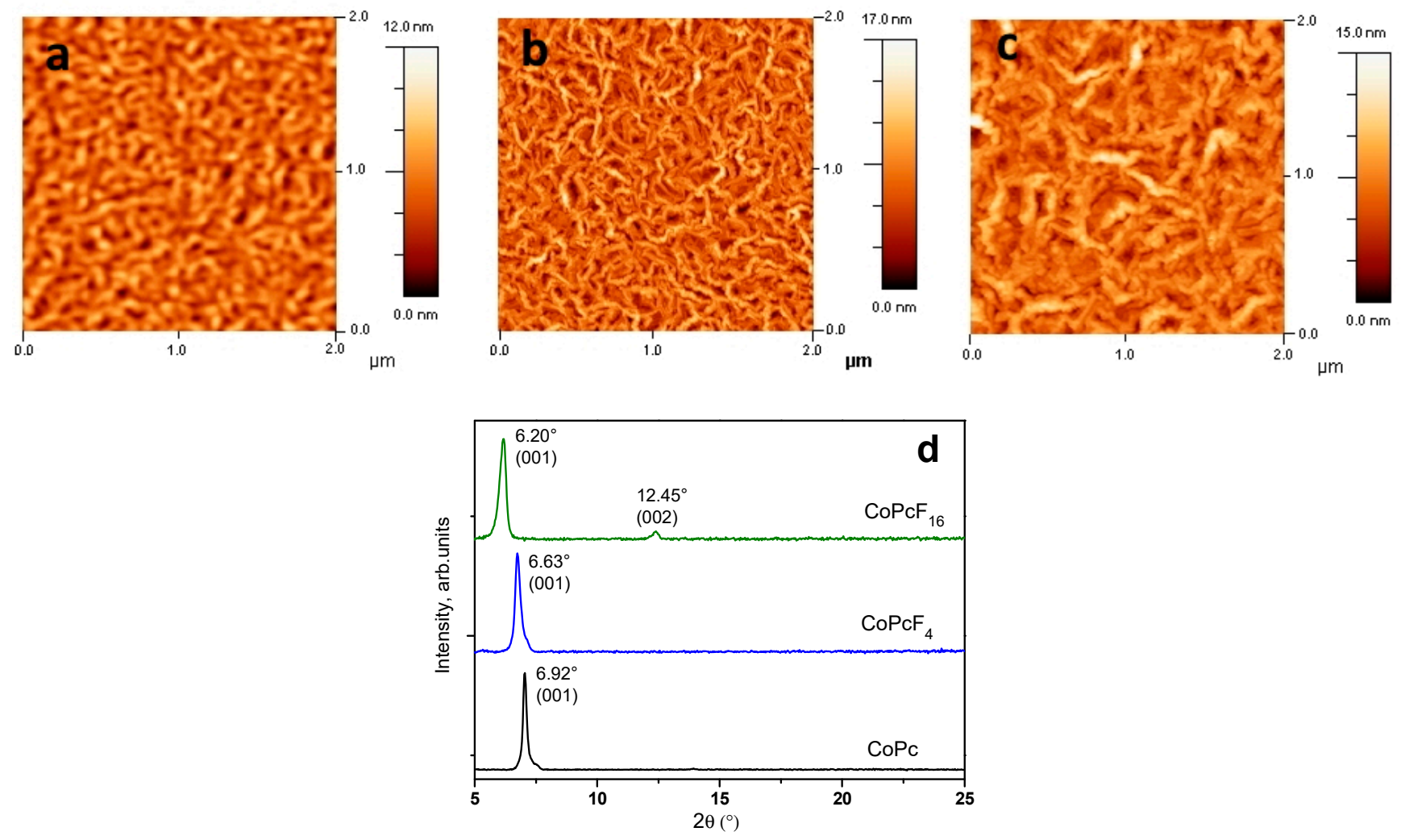

Figure 1. Topographic AFM images $(2 \mu \mathrm{m} \times 2 \mu \mathrm{m})$ of $\mathrm{CoPcF}_{16}$ thin films grown at different elevated substrate temperatures: $100{ }^{\circ} \mathrm{C}(\mathbf{a}), 220^{\circ} \mathrm{C}(\mathbf{b})$, and $290^{\circ} \mathrm{C}(\mathbf{c})$. Adapted from [37] with permission from Elsevier. XRD patterns of $\mathrm{CoPcF}_{\mathrm{x}}(\mathrm{x}=0,4,16)$ thin films (d).

Similarly to the films of unsubstituted metal phthalocyanines, $\mathrm{XRD}$ patterns of $\mathrm{MPcF}_{\mathrm{x}}$ films usually contain a single strong diffraction peak in the range from $5^{\circ}$ to $7^{\circ} 2 \theta$, which is a typical feature of thin films with a strong preferred orientation (Figure 1d).

It was shown that in contrast to $\mathrm{MPc}(\mathrm{M}=\mathrm{Cu}, \mathrm{Co}, \mathrm{Zn})$, which are able to form $\alpha$ and $\beta$-modifications [44,45], $\mathrm{CuPcF}_{4}, \mathrm{CoPcF}_{4}$, and $\mathrm{ZnPcF}_{4}$ crystallize only in one triclinic (P-1 space group) phase [32,46]. At the same time, two polymorphs $\alpha-\mathrm{CuPcF}_{16}(\mathrm{P}-1$ space group, $\mathrm{Z}=1$ ) [47], forming on a substrate at room temperature, and triclinic $\beta-\mathrm{CuPcF}_{16}$ (P-1 space group, $\mathrm{Z}=2$ ) growing on a substrate heated to $360{ }^{\circ} \mathrm{C}$ [48], were identified in the case of $\mathrm{CuPcF}_{16}$. Thin films of fluorinated metal phthalocyanines with non-planar structure (e.g., $\mathrm{PbPcF}_{\mathrm{x}}, \mathrm{VOPcF}_{\mathrm{x}}$, etc.) were also investigated. $\mathrm{PbPc}$ films were shown to consist of two crystal phases, triclinic and monoclinic, while $\mathrm{PbPcF}_{4}$ and $\mathrm{PbPcF}_{16}$ films are single-phase, having the same structures as their single crystals, in tetragonal (I4) and 
triclinic (P-1) space groups, respectively [49]. VOPc and $\mathrm{VOPcF}_{4}$ crystallites have strong preferred orientation relative to the substrate surface [50].

The introduction of fluoroalkyl or fluoroaryl substituents (Compounds 4-16, Table 1) leads to the better solubility of phthalocyanine derivatives in organic solvents [51-53]. For this reason, the drop cast, spin coating and jet spray techniques are used for the preparation of their films on different substrates and electrodes [33,54]. Duan et al. [52] utilized a phasetransfer method for the preparation of the layers of (trifluoromethyl)phenoxy-substituted phthalocyanine derivatives (Compounds 6, Table 1), while Dong and co-authors [55] deposited films of metal-free phthalocyanines bearing trifluoroethoxy-substituents by a solution-based quasi-Langmuir-Shäfer (QLS) method. The structure and morphology of the films were dependent on the phthalocyanines' molecular structure and the deposition technique. For example, the drop-casted films of $\mathrm{ZnPc}\left(\mathrm{OCH}_{2}\left(\mathrm{CF}_{2}\right)_{6} \mathrm{CF}_{3}\right)_{8}$ [56] and $\mathrm{H}_{2} \mathrm{Pc}\left(\mathrm{OCH}_{2}\left(\mathrm{CF}_{2}\right)_{6} \mathrm{CF}_{3}\right)_{4}$ [57] were less crystalline than vacuum-deposited films, and they had a tendency to form J-type molecular stacking structures. The use of a phase-transfer method led to the formation of crystalline films of $\mathrm{M}\left[\mathrm{Pc}\left(\mathrm{OCH}_{2} \mathrm{C}_{3} \mathrm{~F}_{7}\right)_{8}\right](\mathrm{M}=2 \mathrm{H}, \mathrm{Zn})$ [58] and $\mathrm{MPc}\left[\alpha-\mathrm{O}\left(4-\mathrm{CF}_{3}-\mathrm{Ph}\right)_{4}\right](\mathrm{M}=2 \mathrm{H}, \mathrm{Co})[52]$ with a helical ribbon-like structure with a ribbon width of about $1.5-5 \mu \mathrm{m}$ and length over $30 \mu \mathrm{m}$. Thus, when producing layers for chemical sensors, the film-deposition parameters must be strictly controlled, in order to obtain films of a certain phase composition and ordering.

\section{Active Layers of the Devices with Electrical Sensor Response}

To date, metal phthalocyanines with various substituents are widely investigated and utilized as active layers of chemical sensors with electrical response for the detection of different gases due to their semiconductor behavior and ability to change their resistance upon interaction with various gases [59-61]. Among them, fluorinated phthalocyanines are known to use, as active layers of chemical sensors toward ammonia [21,62], chlorine [63,64], nitrogen dioxide $[52,65]$ and hydrogen $[50,66]$. The sensor devices are mostly based on chemiresistors $[21,67,68]$ and organic field effect transistors (OFET) [69]. For the preparation of the standard chemiresistive sensors, films are deposited onto the substrates with interdigitated electrodes. In the case of OFET, there is a broad range of various configuration designs, as summarized in a recent review article on gas sensors based on OFET structures (Figure 2) [70].

It is known that the introduction of electron-withdrawing substituents, such as fluorine, can change the charge transport properties of metal phthalocyanines from p-type to n-type. For instance, $\mathrm{MPc}(\mathrm{M}=\mathrm{Cu}, \mathrm{Co}, \mathrm{Zn})$ are typical p-type materials, while the corresponding $\mathrm{MPcF}_{16}$ derivatives demonstrate n-type semiconductor behavior [71]. $\mathrm{MPcF}_{4}$ $(\mathrm{M}=\mathrm{Cu}, \mathrm{Co}, \mathrm{Zn})$ are known to exhibit both p-type and n-type behavior, depending on central metals and environment [72]. For this reason, fluorinated metal phthalocyanines are widely used as an active layer in both unipolar and ambipolar transistors combining bilayer structures or blends of $n$ - and p-type MPcs $[9,20,73]$.

Bouvet et al. [74] suggested one more principle of transduction based on molecular semiconductor-doped insulator (MSDI) heterojunction (Figure 3). 
(a)
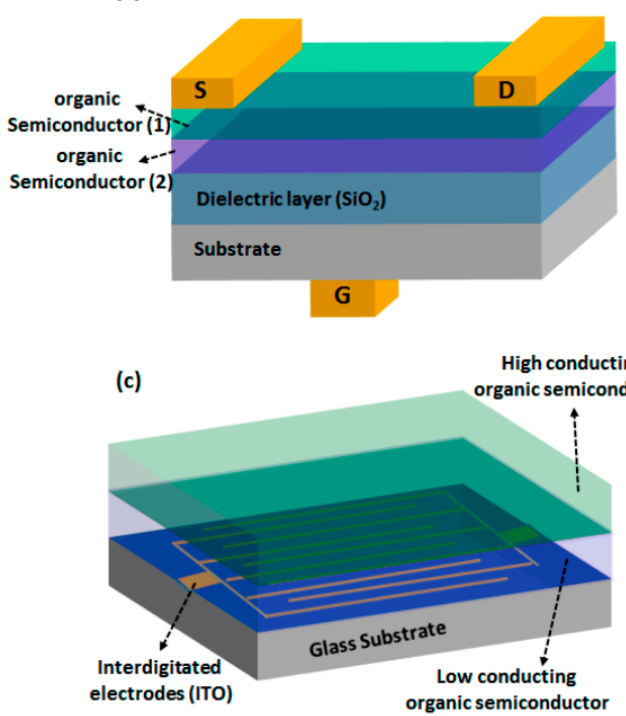

(b)
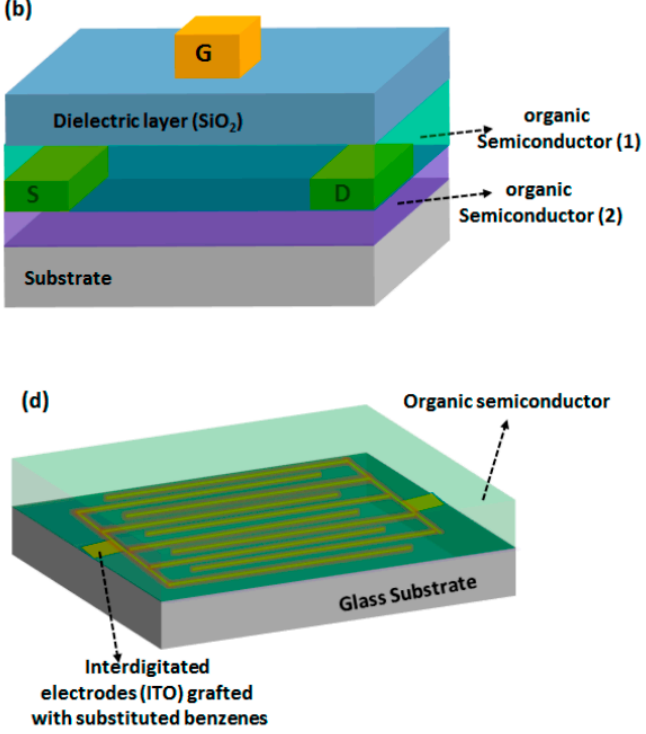

Figure 2. Scheme of OFET device designs in suspended gate (a) and top gate (b) configuration. Scheme of MSDI (c) and double lateral heterojunction (d) device [75].

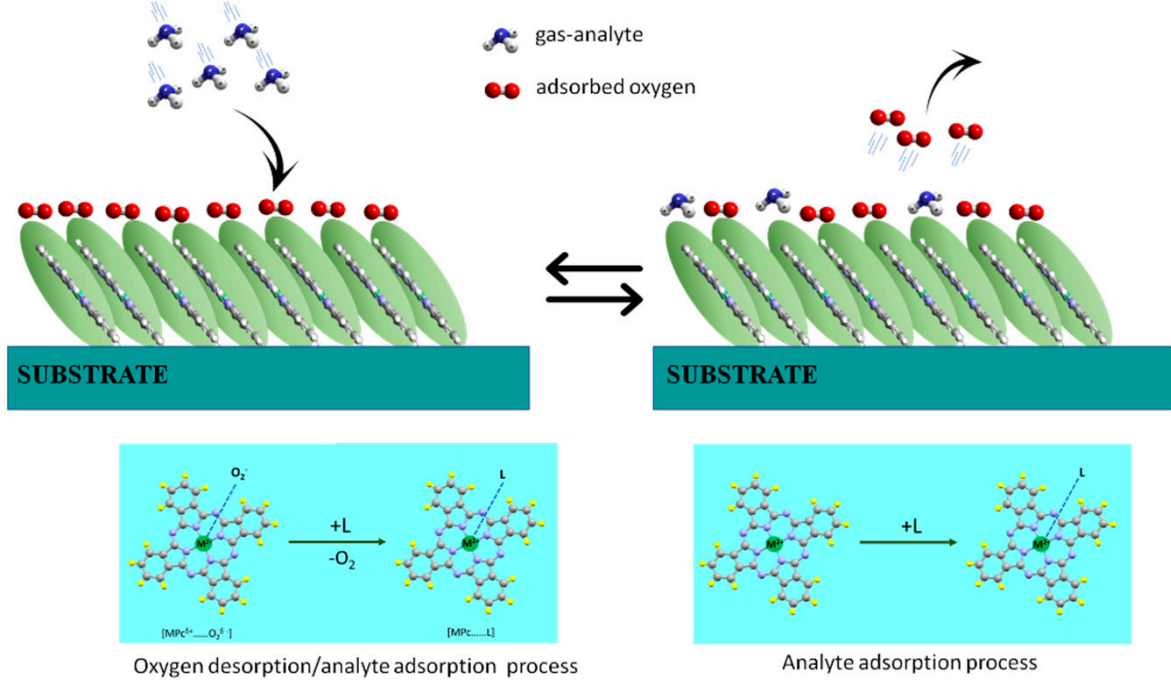

Figure 3. Schematic diagram of the sensing mechanisms of MPc sensors.

In short, the principle of operation is in the tuning effect exerted by the doped insulator layer at the level of the heterojunction in the electronic properties of the $\mathrm{LuPc}_{2}$ semiconductor, which demonstrates inverted sensor response to accepting and donating analyte molecules. This idea was described in more detail in their recent review [75]. In such molecular semiconductor-doped insulator heterojunction structures the top layer (e.g., $\mathrm{LuPc}_{2}$ ) has a very high carrier concentration, while such relatively poor semiconductors as fluorinated metal phthalocyanines are used as sublayers. Electrons and holes at definite conditions may be injected in the sublayer, which justify their name as molecular semiconductor-doped insulators [75].

The main characteristics of sensors with electrical sensor response with fluorinated metal phthalocyanines as active layers are summarized in Table 2. 
Table 2. Main characteristics of sensors on the basis of fluorinated metal phthalocyanines.

\begin{tabular}{|c|c|c|c|c|c|c|}
\hline Active Layer & Sensor Type & Analyte & $\begin{array}{l}\text { Investigated } \\
\text { Range, Ppm }\end{array}$ & LOD, Ppm & Recovery Time, $S$ & Ref. \\
\hline $\mathrm{ZnPcF}_{16}$ & Chemiresistive & $\begin{array}{c}\mathrm{NH}_{3} \text { in } \mathrm{N}_{2} \\
\mathrm{H}_{2} \text { in } \mathrm{N}_{2}\end{array}$ & $\begin{array}{l}0-1000 \\
0-2000\end{array}$ & $\mathrm{n} / \mathrm{a}$ & Several hours & {$[76]$} \\
\hline $\mathrm{ZnPcF}_{16}$ & Chemiresistive & $\begin{array}{c}\mathrm{NH}_{3}, \mathrm{~N}\left(\mathrm{CH}_{3}\right)_{3} \\
\mathrm{NH}_{2} \mathrm{CH}_{3} \\
\mathrm{~N}\left(\mathrm{C}_{2} \mathrm{H}_{5}\right)_{3} \\
\end{array}$ & $0.72\left(\mathrm{NH}_{3}\right)$ & $\mathrm{n} / \mathrm{a}$ & $\mathrm{n} / \mathrm{a}$ & [77] \\
\hline $\mathrm{CoPcF}_{4}$ & Chemiresistive & $\mathrm{NH}_{3}$ & $10-50$ & 2.5 & $30(20 \mathrm{ppm})$ & [62] \\
\hline $\mathrm{PdPcF}_{16}$ & Chemiresistive & $\begin{array}{c}\mathrm{NH}_{3} \\
\mathrm{H}_{2}\end{array}$ & $\begin{array}{c}10-50 \\
1000-5000\end{array}$ & $\begin{array}{l}\mathrm{n} / \mathrm{a} \\
500\end{array}$ & $\begin{array}{c}55(10 \mathrm{ppm}) \\
60(1000 \mathrm{ppm})\end{array}$ & [68] \\
\hline $\begin{array}{c}\mathrm{MPcF}_{\mathrm{x}}(\mathrm{M}=\mathrm{Cu}, \mathrm{Co}, \mathrm{Zn}, \\
\mathrm{x}=4,16)\end{array}$ & Chemiresistive & $\mathrm{NH}_{3}$ & $0.1-50$ & 0.1 (for $\mathrm{ZnPcF}_{4}$ ) & $\begin{array}{l}110(10 \mathrm{ppm}) \\
\left(\text { for } \mathrm{ZnPcF}_{4}\right)\end{array}$ & [21] \\
\hline $\begin{array}{l}\mathrm{PbPcF}_{4} \\
\mathrm{PbPcF}_{16}\end{array}$ & Chemiresistive & $\mathrm{NH}_{3}$ & $1-5$ & $\mathrm{n} / \mathrm{a}$ & $90-220$ & [49] \\
\hline $\mathrm{VOPcF}_{4}$ & Chemiresistive & $\begin{array}{c}\mathrm{NH}_{3} \\
\mathrm{H}_{2}\end{array}$ & $\begin{array}{c}10-50 \\
10-500\end{array}$ & $\mathrm{n} / \mathrm{a}$ & $\begin{array}{l}230(30 \mathrm{ppm}) \\
50(300 \mathrm{ppm})\end{array}$ & [50] \\
\hline $\begin{array}{l}\mathrm{CuPcF}_{16} / \mathrm{pNIDPP} \\
\mathrm{CuPcF}_{16} / \mathrm{pNIDMP}^{2}\end{array}$ & MSDI & $\mathrm{NH}_{3}$ & $1-50$ & $\begin{array}{c}\sim 1 \\
0.228\end{array}$ & $\mathrm{n} / \mathrm{a}$ & [78] \\
\hline $\mathrm{CuPcF}_{16} / \mathrm{LuPc}_{2}$ & MSDI & $\mathrm{NH}_{3}$ & $30-90$ & $\mathrm{n} / \mathrm{a}$ & $\mathrm{n} / \mathrm{a}$ & [79] \\
\hline $\begin{array}{c}\mathrm{CuPcF}_{16} / \mathrm{LuPc}_{2} \text { on bare ITO } \\
\mathrm{CuPcF}_{16} / \mathrm{LuPc}_{2} \text { on } \\
\mathrm{DMBz} / \mathrm{ITO}\end{array}$ & MSDI & $\mathrm{NH}_{3}$ & $1-90$ & $\begin{array}{l}0.28(\text { RH } 50 \%) \\
0.14(\text { RH } 50 \%)\end{array}$ & $\mathrm{n} / \mathrm{a}$ & [80] \\
\hline $\left.\mathrm{CuPcF}_{\mathrm{n}} / \mathrm{LuPc}_{2}, \mathrm{n}=8,16\right)$ & MSDI & $\begin{array}{l}\mathrm{O}_{3} \text { in air } \\
\mathrm{NH}_{3} \text { in } \mathrm{Ar}\end{array}$ & $\begin{array}{l}0.09\left(\mathrm{O}_{3}\right) \\
35\left(\mathrm{NH}_{3}\right)\end{array}$ & $\mathrm{n} / \mathrm{a}$ & $\mathrm{n} / \mathrm{a}$ & [74] \\
\hline $\mathrm{CuPcF}_{16}$ & OFET & $\begin{array}{l}\text { DMMP } \\
\text { Methanol }\end{array}$ & $\begin{array}{c}5-60 \\
200-1650\end{array}$ & $\mathrm{n} / \mathrm{a}$ & $>1 \mathrm{~h}$ & [69] \\
\hline $\mathrm{TiOPc}_{\mathrm{CuPcF}} \mathrm{Cu}_{16}$ & OTFT & $\mathrm{NO}_{2}$ & $<5$ & 0.25 & $\mathrm{n} / \mathrm{a}$ & [81] \\
\hline $\mathrm{CuPcF}_{16} / \mathrm{CuPc}$ & OTFT & $\mathrm{NO}_{2}$ & 20 & 20 & $\mathrm{n} / \mathrm{a}$ & [65] \\
\hline $\begin{array}{l}\mathrm{CoPc}\left[\beta-\mathrm{O}\left(4-\mathrm{CF}_{3}-\mathrm{Ph}\right)_{4}\right] \\
\mathrm{H}_{2} \mathrm{Pc}\left[\beta-\mathrm{O}\left(4-\mathrm{CF}_{3}-\mathrm{Ph}\right)_{4}\right] \\
\mathrm{CoPc}\left[\alpha-\mathrm{O}\left(4-\mathrm{CF}_{3}-\mathrm{Ph}\right)_{4}\right] \\
\mathrm{H}_{2} \mathrm{Pc}\left[\alpha-\mathrm{O}\left(4-\mathrm{CF}_{3}-\mathrm{Ph}\right)_{4}\right] \\
(\text { Compounds 6, Table 1) }\end{array}$ & Chemiresistive & $\begin{array}{l}\mathrm{NO}_{2} \\
\mathrm{NH}_{3} \\
\mathrm{H}_{2} \mathrm{~S}\end{array}$ & $\begin{array}{l}\text { Dependent on } \\
\text { the analyte }\end{array}$ & $\begin{array}{c}0.003 \\
0.03 \\
0.198 \\
0.25\left(\text { to } \mathrm{NO}_{2}\right)\end{array}$ & $\mathrm{n} / \mathrm{a}$ & [52] \\
\hline $\begin{array}{c}\mathrm{H}_{2} \mathrm{Pc}\left(\mathrm{OCH}_{2} \mathrm{CF}_{3}\right)_{4} \\
\text { (Compound 8, Table 1) }\end{array}$ & Chemiresistive & $\mathrm{NO}_{2}$ & $0.1-0.5$ & $\mathrm{n} / \mathrm{a}$ & $420(500 \mathrm{ppb})$ & [55] \\
\hline $\begin{array}{c}\mathrm{H}_{2}\left[\mathrm{Pc}\left(\mathrm{OCH}_{2} \mathrm{C}_{3} \mathrm{~F}_{7}\right)_{8}\right] \\
\mathrm{Zn}\left[\mathrm{Pc}\left(\mathrm{OCH}_{2} \mathrm{C}_{3} \mathrm{~F}_{7}\right)_{8}\right] \\
(\text { Compounds 10, Table 1) }\end{array}$ & Chemiresistive & $\mathrm{NO}_{2}$ & $\begin{array}{c}50-900 \\
100-750\end{array}$ & $\begin{array}{c}50 \\
100\end{array}$ & $\mathrm{n} / \mathrm{a}$ & [58] \\
\hline $\begin{array}{l}\mathrm{H}_{2}\left[\mathrm{Pc}\left(\mathrm{OCH}_{2}\left(\mathrm{CF}_{2}\right)_{6} \mathrm{CF}_{3}\right)_{4}\right] \\
\text { (Compound 9, Table 1) }\end{array}$ & Chemiresistive & $\mathrm{NO}_{2}$ & $0.1-1$ & $\mathrm{n} / \mathrm{a}$ & $180(0.5 \mathrm{ppm})$ & [57] \\
\hline $\begin{array}{c}\mathrm{CoPcR}_{8} \\
\text { (Compound 12, Table 1) }\end{array}$ & Chemiresistive & $\mathrm{NH}_{3}$ & $0.3-50$ & 0.3 & 40 (5 ppm) & [51] \\
\hline $\begin{array}{c}\mathrm{Gd}_{2}\left[\mathrm{Pc}(\mathrm{OPhF})_{8}\right]_{3} \\
\mathrm{~Tb}_{2}\left[\mathrm{Pc}(\mathrm{OPhF})_{8}\right]_{3} \\
\text { (Compounds 11, Table 1) }\end{array}$ & Chemiresistive & $\mathrm{NH}_{3}$ & $1-20$ & - & $\begin{array}{c}126 \\
103(20 \mathrm{ppm})\end{array}$ & [82] \\
\hline $\mathrm{CuPcF}_{16} / \mathrm{rGO}$ & Chemiresistive & $\mathrm{Cl}_{2}$ & $0.06-3$ & $1.41 \cdot 10^{-3}$ & 551 & [83] \\
\hline $\mathrm{CoPcF}_{16} / \mathrm{SWCNT}$ & Chemiresistive & $\mathrm{Cl}_{2}$ & $0.04-2$ & $0.05 \cdot 10^{-3}$ & $150(500 \mathrm{ppb})$ & [84] \\
\hline $\begin{array}{l}\mathrm{CuPcF}_{16} / \mathrm{SWCNT} \\
\mathrm{CuPcF}_{16} / \mathrm{MWCNT}\end{array}$ & Chemiresistive & $\mathrm{Cl}_{2}$ & $0.1-2$ & $\begin{array}{l}0.27 \cdot 10^{-3} \\
0.85 \cdot 10^{-3}\end{array}$ & $\mathrm{n} / \mathrm{a}$ & [63] \\
\hline $\begin{array}{c}\mathrm{MPcF}_{16} / \mathrm{SWCNT}(\mathrm{M}=\mathrm{Co} \\
\mathrm{Zn}, \mathrm{Cu})\end{array}$ & Chemiresistive & $\mathrm{Cl}_{2}$ & $0.04-2$ & $0.04 \cdot 10^{-3}$ & $\mathrm{n} / \mathrm{a}$ & [85] \\
\hline $\mathrm{ZnPcF}_{16} / \mathrm{MWCNT}$ & Chemiresistive & $\mathrm{Cl}_{2}$ & $0.01-2$ & $0.06 \cdot 10^{-3}$ & $\mathrm{n} / \mathrm{a}$ & [64] \\
\hline $\begin{array}{l}\text { Compound } 7 \\
\text { (Table 1)/SWCNT }\end{array}$ & Chemiresistive & $\mathrm{NH}_{3}$ & $1-50$ & 0.78 & 170 (10 ppm) & [86] \\
\hline
\end{tabular}




\subsection{Sensors Based on $M P c F_{x}$ Films Obtained by PVD}

The literature analysis shows that the films of $\mathrm{MPcF}_{\mathrm{x}}(\mathrm{x}=4,8,16)$ with $\mathrm{M}=\mathrm{Cu}$, $\mathrm{Co}, \mathrm{Pd}, \mathrm{Zn}, \mathrm{VO}$ are most widely used as active layers of sensors for ammonia detection. It was shown that fluorine substituents decrease the electron density of the aromatic ring and increase the oxidation potential of the MPc molecule [87]. As a result, fluorosubstituted phthalocyanines exhibit a higher sensor response to reducing gases [88] such as ammonia. Schollhorn et al. [76] were the first to show that hexadecafluoro-substituted zinc phthalocyanine $\mathrm{ZnPcF}_{16}$ films prepared by vacuum evaporation exhibited a higher sensitivity to gaseous ammonia and hydrogen than their unsubstituted analogues. Their conductivity was measured during exposure to the reducing gases $\mathrm{NH}_{3}$ and $\mathrm{H}_{2}$ diluted in $\mathrm{N}_{2}$. Later, Xingfa Ma and coworkers [77] compared the sensitivity of $\mathrm{ZnPc}$ and $\mathrm{ZnPcF}_{16}$ films to ammonia, trimethylamine and methylamine and found that fluorination led to a significant improvement in sensitivity. $\mathrm{ZnPcF}_{16}$ films were shown to have good selectivity and stability and to recover completely after purging with high-purity $\mathrm{N}_{2}$ at room temperature.

More systematic studies of the sensor response of $\mathrm{MPcF}_{\mathrm{x}}(\mathrm{M}=\mathrm{Cu}, \mathrm{Co}, \mathrm{Zn}, \mathrm{Pd}, \mathrm{VO}$, $\mathrm{Pb} ; \mathrm{x}=4,16$ ) films toward gaseous $\mathrm{NH}_{3}$ were carried out by our research group using a chemiresistive method. The sensor response of $\mathrm{MPcF}_{\mathrm{x}}$ was compared with that of unsubstituted MPc films to reveal the effects of F-substituents and central metals on the sensing performance (Table 2) $[21,49,50,62,68]$. The effect of F-substituents on the sensor response to $\mathrm{NH}_{3}$ was studied using films of zinc, copper and cobalt phthalocyanine derivatives $\mathrm{MPcF}_{\mathrm{x}}$ $(x=0,4,16)$ as examples [21] (Figure 4). It is important to mention that the introduction of gaseous $\mathrm{NH}_{3}$ to the gas chamber leads to an increase in the resistance of $\mathrm{MPcF}_{4}$ films (Figure 4a). This behavior was typical for p-type organic semiconductors and was also observed for the films of unsubstituted metal phthalocyanines [89]. In contrast to MPc and $\mathrm{MPcF}_{4}, \mathrm{MPcF}_{16}$ films demonstrate a decrease in their resistance upon interaction with electron donor $\mathrm{NH}_{3}$ molecules (Figure $4 \mathrm{~b}$ ). It is known that $\mathrm{MPcF}_{16}$ films demonstrate n-type semiconducting behavior due to the effect of electron-withdrawing F-substituents [90].
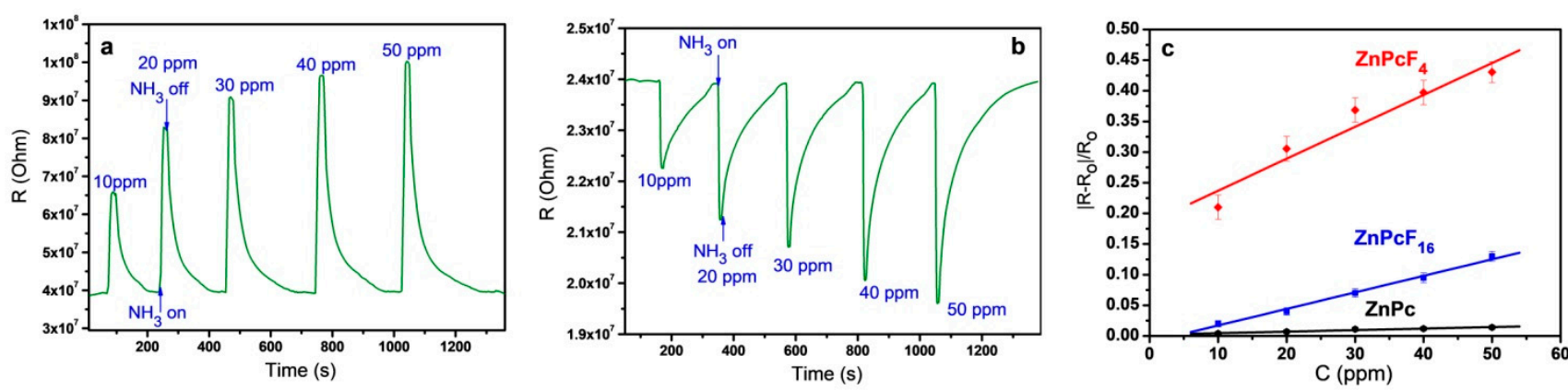

Figure 4. Sensor response of $\mathrm{CoPcF}_{4}(\mathbf{a})$ and $\mathrm{CoPcF}_{16}$ films (b) to ammonia. Dependence of the sensor response of $\mathrm{ZnPcF}_{\mathrm{x}}$ $(\mathrm{x}=0,4,16)$ films on ammonia concentration $(\mathbf{c})[21]$.

According to the mechanism of semiconductor sensors described in the literature [91,92], the formation of charge-transfer complexes by coordination of $\mathrm{O}_{2}$ to MPc occurs at the air/MPc interface and at grain boundaries, which leads to the formation of oxidized $\mathrm{MPc}^{+}$and $\mathrm{O}^{2-}$ species $[93,94]$. When a p-type semiconductor gas sensor is exposed to the reducing gases (e.g., $\mathrm{NH}_{3}$ ), the electrons injected into the material through the oxidation reaction between the reducing gas and the $\mathrm{O}^{2-}$ species on the semiconductor surface decrease the concentration of holes in the layer, which in turn increases the resistance of MPc film [95]. A schematic diagram of the sensing mechanisms of MPc sensors is shown in Figure 3. When an n-type semiconductor is exposed to a reducing gas, ionized oxygen anions are used to oxidize the reducing gas, and the released electrons inject into the semiconducting core, which decreases the sensor resistance proportionally to the concentration of reducing gas-analyte [92]. In the case of oxidizing gases (e.g., $\mathrm{NO}_{2}$, $\mathrm{Cl}_{2}$ ) a surface adsorption mechanism is also used. In contrast to reducing gases, the 
doping of n-type semiconductor by $\mathrm{NO}_{2}$ leads to the capture of carriers, thereby reducing their current [55].

Although observations of changes in the measured current of MPc sensing layers exposed to $\mathrm{NH}_{3}$ and other analytes are explained by electron transfer, the interaction sites in the phthalocyanine macrocycle or metal center are still a matter of discussion. According to the data of most works, the most energetically favorable cite of $\mathrm{NH}_{3}$ and $\mathrm{NO}_{2}$ molecule binding is the central metal of MPc molecules [96-99]. These conclusions were based only on the quantum chemical calculations. At the same time, the experimental investigations of the interaction sites are sporadic [10,100]. For example, Saini et al. [100] used Raman spectroscopy and X-ray photoelectron spectroscopy (XPS) for investigation of interaction of $\mathrm{CuPcR}_{4}\left(\mathrm{R}=-\mathrm{OC}_{4} \mathrm{H}_{7}\right)$ with chlorine. They found a shift of the bands at 253 and $1529 \mathrm{~cm}^{-1}$, which were attributed to the $\mathrm{Cu}-\mathrm{N}_{\alpha}$ stretching vibration and the vibration associated with the cavity change in the phthalocyanine macrocycle, respectively, after interaction with $\mathrm{Cl}_{2}$. That was in good correlation with the shift of $\mathrm{Cu} 2 \mathrm{p}$ peaks in XPS spectrum of the exposed films. Thus, the studies revealed that central metal ions of $\mathrm{CuPcR}_{4}$ molecules were the predominant sites of $\mathrm{Cl}_{2}$ absorption. Chia et al. [10] used in situ X-ray absorption spectroscopy (XAS) to investigate the interaction of $\mathrm{CuPc}$ with $\mathrm{NH}_{3}$ and $\mathrm{NO}_{2}$ molecules. In contrast to the previous case, the first derivative of XANES suggested low or a lack of axial position coordination on the $\mathrm{Cu}$ metal center. On the other hand, the interaction on the macrocycle was supported by the EXAFS. From the EXAFS of CuPc with $\mathrm{NO}_{2}$, the interaction was suggested to be at the pyrrole moiety of the Pc macrocycle, while in the case of $\mathrm{NH}_{3}$ on the benzo moiety or bridging atom. The experimental investigations of the interaction sites in the case of fluorinated MPcs were not carried out.

It was also shown that the sensor response decreased in the order of $\mathrm{MPcF}_{4}>\mathrm{MPcF}_{16}>\mathrm{MPc}$ (Figure 4). $\mathrm{MPcF}_{4}$ films showed the highest sensor response to ammonia among the investigated phthalocyanines; their response was 3-10 times higher than that of $\mathrm{MPcF}_{16}$ films, and 30-70 times higher than that of MPc films. All films exhibited a reversible sensor response at room temperature, with the response time of $10-25 \mathrm{~s}$ and recovery time no more than 2 min [21].

The sensor response toward ammonia changed also in the same order for lead phthalocyanine derivatives PbPcF4 $>\mathrm{PbPcF} 16>\mathrm{PbPc}$, and the sensors demonstrated completely reversible sensor response at room temperature [49]. The effect of central metals on the sensor response of $\mathrm{MPcF}_{4}$ and $\mathrm{MPcF}_{16}$ to $\mathrm{NH}_{3}$ was also investigated by our group. Figure 5 summarizes the data on the dependence of the sensor response of $\mathrm{MPcF}_{4}$ and $\mathrm{MPcF}_{16}$ $(\mathrm{M}=\mathrm{Cu}, \mathrm{Co}, \mathrm{Zn}, \mathrm{Pb}, \mathrm{VO})$ on $\mathrm{NH}_{3}$ concentration.
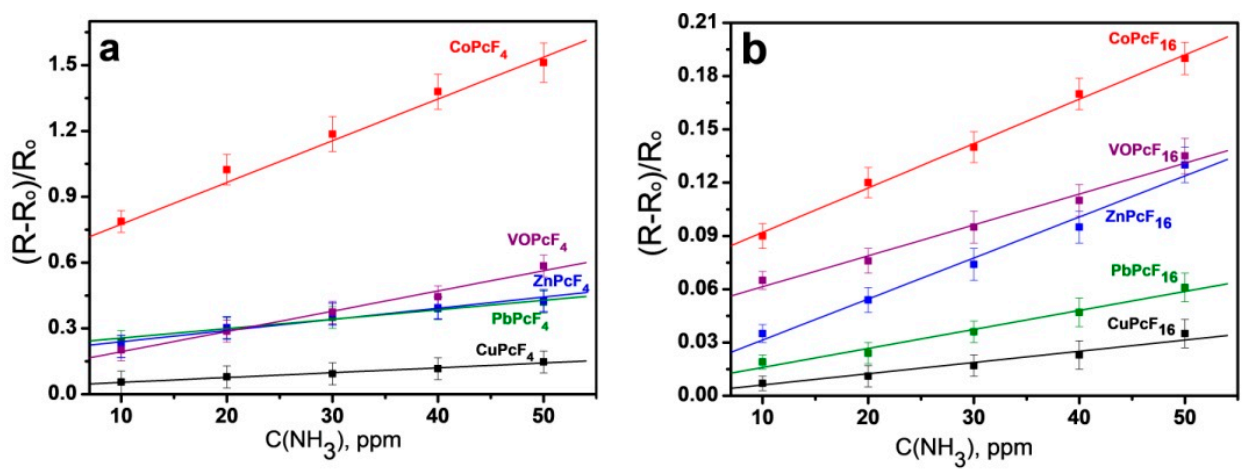

Figure 5. Dependence of the sensor response of $\mathrm{MPcF}_{\mathrm{x}}(\mathrm{M}=\mathrm{Co}, \mathrm{VO}, \mathrm{Zn}, \mathrm{Pb}, \mathrm{Cu}, \mathrm{x}=4(\mathbf{a}), 16$ (b)) films on ammonia concentration.

Both in the case of tetrafluorinated and perfluorinated derivatives, the sensor response decreased in the order $\mathrm{Co}>\mathrm{VO} \sim \mathrm{Zn}>\mathrm{Pb}>\mathrm{Cu}$. The data for phthalocyanines of $\mathrm{Co}, \mathrm{Zn}$ and $\mathrm{Cu}$ were in reasonably good correlation with the results of quantum chemical calculations of the binding energy between $\mathrm{NH}_{3}$ and phthalocyanine molecules as well as changes in the values of effective charge on $\mathrm{NH}_{3}$ molecule. 
More detailed study of the performance of $\mathrm{ZnPcF}_{4}$-based sensor were performed by Klyamer et al. [21]. $\mathrm{ZnPcF}_{4}$ films were shown to exhibit the detection limit of ammonia $0.1 \mathrm{ppm}$, and can be used for its selective detection in the presence of some reducing gases and volatile organic compounds, namely acetone, dichloromethane, carbon dioxide and ethanol (Figure 6). Moreover, the $\mathrm{ZnPcF}_{4}$ films can be used for the detection of $\mathrm{NH}_{3}$ in the gas mixture simulating exhaled air $\left(\mathrm{N}_{2} 76 \%, \mathrm{O}_{2} 16 \%, \mathrm{H}_{2} \mathrm{O} 5 \%\right.$, and $\left.\mathrm{CO}_{2} 3 \%\right)$ and at relative air humidity up to $70 \%$.
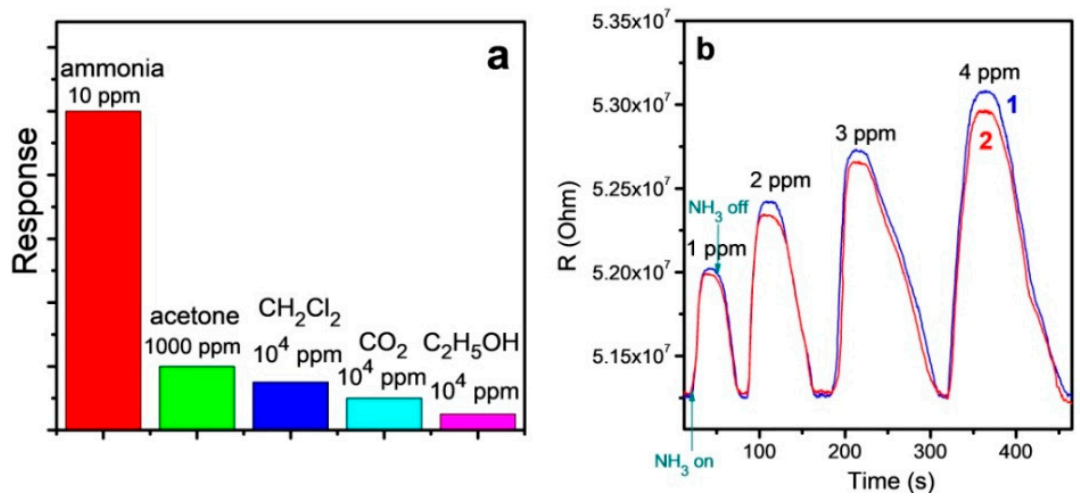

Figure 6. (a) Response of a $\mathrm{ZnPcF}_{4}$ film to ammonia (10 ppm), acetone (1000 ppm), dichloromethane (104 ppm), carbon dioxide (104 ppm), ethanol (104 ppm). (b) Sensor response of a $\mathrm{ZnPcF}_{4}$ layer toward ammonia in the concentration range from 1 to $4 \mathrm{ppm}$, in air (1) and in a mixture of gases with the composition close to exhaled air of healthy people $\left(\mathrm{N}_{2}, 76 \% ; \mathrm{O}_{2}, 16 \% ; \mathrm{H}_{2} \mathrm{O}, 5 \%\right.$; and $\left.\mathrm{CO}_{2}, 3 \%\right)$ (2) [21].

Apart from the sensors to ammonia, $\mathrm{MPcF}_{\mathrm{x}}$ films are utilized as active layers of chemiresistive sensors for the detection of hydrogen. For example, Parkhomenko et al. [68] compared the sensor response of $\mathrm{PdPcF}_{16}$ films to hydrogen (1000-5000 ppm) with that of PdPc films. It was found that the sensitivity of PdPc film to hydrogen was slightly higher than that of the $\mathrm{PdPcF}_{16}$ film. $\mathrm{VOPcF}_{4}$ were shown to be also sensitive to hydrogen [50], but, similarly to palladium derivatives, the sensor response of $\mathrm{VOPcF}_{4}$ film was slightly less than in the case of unsubstituted vanadyl phthalocyanines films.

Fluorinated MPc-based organic filed effect transistors (OFET) or organic thin film transistors (OTFT) with $\mathrm{p}-\mathrm{n}$ heterojunction were also investigated for detecting various gases and volatile organic compounds (Table 2). For example, Yang et al. [69] prepared OFET structures with $\mathrm{CuPcF}_{16}$ as an n-type semiconductor and $\mathrm{SiO}_{2}$ as a dielectric, and tested them as active layers of sensors for the detection of dimethyl methylphosphonate (DMMP) and methanol in comparison with similar OFETs on the basis of p-type CuPc layers. Other analytes, namely diisopropyl methylphosphonate (DIMP), $\mathrm{H}_{2} \mathrm{O}$ and nitrobenzene, were also determined to check the sensor selectivity. It was shown that the responses were of opposite sign for n-type and p-type OFETs for all five analytes. The authors observed a difference in sensitivity to DMMP (68 ppm) and $\mathrm{MeOH}$ (1520 ppm): at the same concentration, the n-channel OFET $\left(\mathrm{CuPcF}_{16}\right)$ had the larger response to DMMP than the p-channel analogue $(\mathrm{CuPc})$, while the p-channel OFET had the larger response to $\mathrm{MeOH}$ than the n-channel transistor (Figure 7).

Modulation of interfacial charge alignments by molecular engineering in organic heterojunction devices is a promising strategy to improve their conductivity and sensor sensitivity. Sensing properties of the heterojunction devices based on fluorinated metal phthalocyanines are widely investigated. Wang [81] and Zhang [65], with their coauthors, reported the results of investigations of an OTFT sensor with $\mathrm{p}-\mathrm{n}$ heterojunction in $\mathrm{MPcF}_{16} / \mathrm{MPc}$ thin films. A sensor device based on a ultra-thin TiOPc film as a bottom layer and $\mathrm{CuPcF}_{16}$ film as a top layer demonstrated an increased relative sensor response to nitrogen dioxide below $5 \mathrm{ppm}$ with a detection limit of up to $250 \mathrm{ppb}$ at room temperature (Figure 8) [81]. 

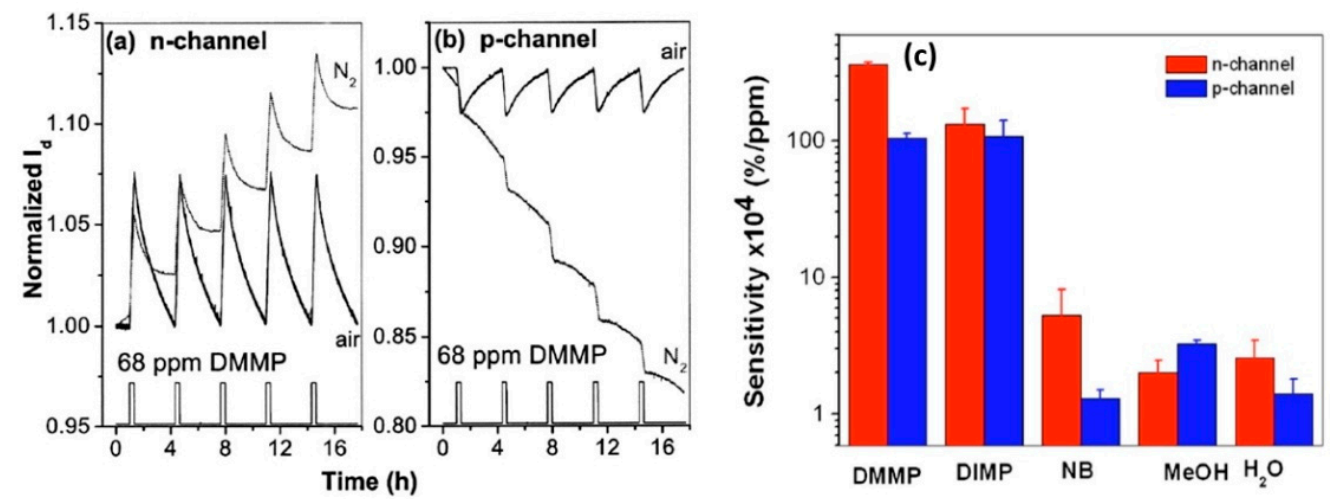

Figure 7. (a) Chemical responses of $n$-channel $\mathrm{CuPcF}_{16}$ (a) and p-channel CuPc (b) ChemFETs to DMMP in air and $\mathrm{N}_{2}$ at $25^{\circ} \mathrm{C}$. (c) The sensitivities of $\mathrm{n}$ - and $\mathrm{p}$-channel ChemFETs to nerve agent simulants (DMMP and DIMP) and other analytes: $\mathrm{MeOH}, \mathrm{H}_{2} \mathrm{O}$, and $\mathrm{NB}$ at $25^{\circ} \mathrm{C}$. The sensitivity is in logarithmic scale. Reprinted from [69] with permission from AIP Publishing.
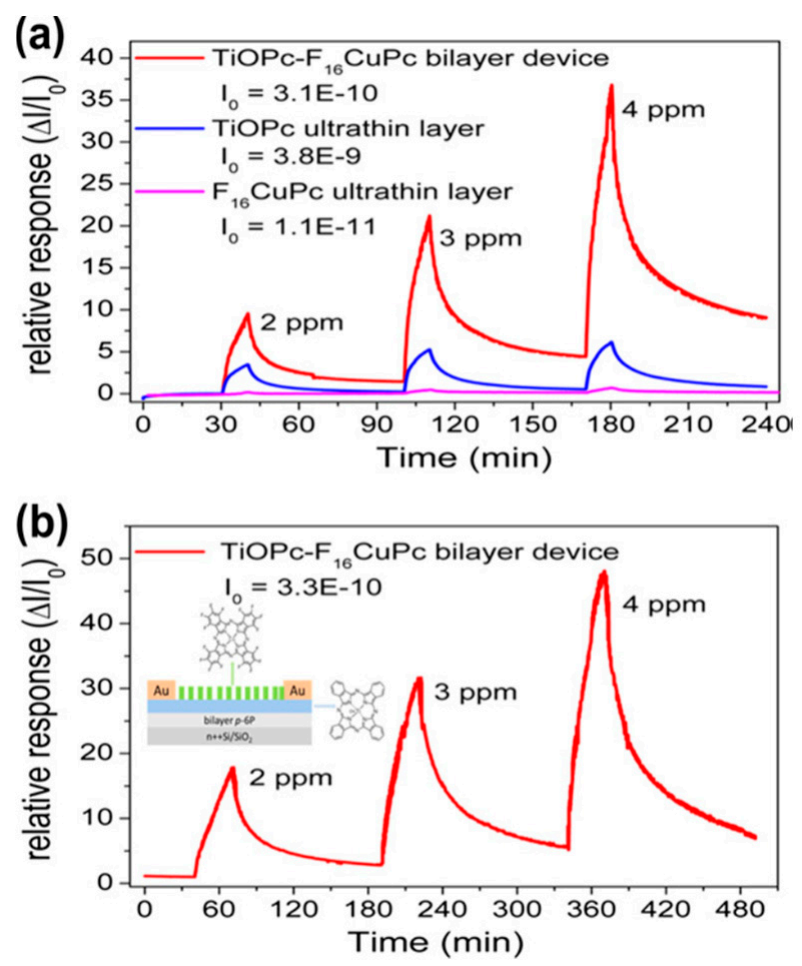

Figure 8. (a) Relative response of the three devices to $\mathrm{NO}_{2}$ pulse as a function of time. The relative response is defined as normalized increase in device current. (b) The section view of bilayer device structure and the molecular structure of $\mathrm{CuPcF}_{16}$ and TiOPc. Reprinted from [82] with permission from Elsevier.

Similar heterojunction organic thin film transistors based n-type $\mathrm{CuPcF}_{16}$ and p-type $\mathrm{CuPc}$ were also utilized to detect $\mathrm{NO}_{2}$ [65]. The authors investigated the effect of $\mathrm{CuPc}$ film thickness in the range from 5 to $20 \mathrm{~nm}$ on the devices' performance. It was found that the sensor with a CuPc film with a thickness of $15 \mathrm{~nm}$ had optimal sensing characteristics.

Bouvet and co-authors in the series of works $[74,79,80]$ demonstrated that conductometric gas sensing devices based on organic heterojunction between poor conducting and high conducting organic semiconductors had high sensitivity and selectivity toward redox gases (Table 2). The sensing devices benefited from the organic heterojunction effects, in which opposite charges $\left(\mathrm{e}^{-}\right.$and $\mathrm{h}+$ ) were accumulated at the interface of a bilayer film because of the work function difference between the semiconducting layers, enhancing the charge carriers mobility along the interface. For this purpose, they used a combination 
of a $\mathrm{CuPcF}_{\mathrm{x}}\left(\mathrm{x}=8\right.$ or 16) film as a poor conducting layer and $\mathrm{LuPc}_{2}$ as a high conducting layer in a bilayer heterojunction configuration $[74,79,80]$ (Figure 9). It was found that the n-MSDI on the basis of $\mathrm{LuPc}_{2}$ and $\mathrm{CuPcF}_{16}$ thin films exhibited a response to $\mathrm{NH}_{3}$ opposite to that of a $\mathrm{LuPc}_{2}$ resistor, and the relative response was ca. seven times higher [74]. Apart from this, it was less sensitive to the presence of humidity in air. The same group of authors in their other work demonstrated that the modification of ITO substrate via electrografting of 1,4-dimethoxybenzene led to an increase in the n-MSDI sensitivity from 1.5 to $3 \% \mathrm{ppm}^{-1}$ in the range of $1-9 \mathrm{ppm}$, compared to n-MSDI without surface modification (Table 2) [80]. This effect appeared to be due to the change in interfacial energy barrier resulted from the modification of the electrode work function, because of the formation of interface dipoles [101].

a)
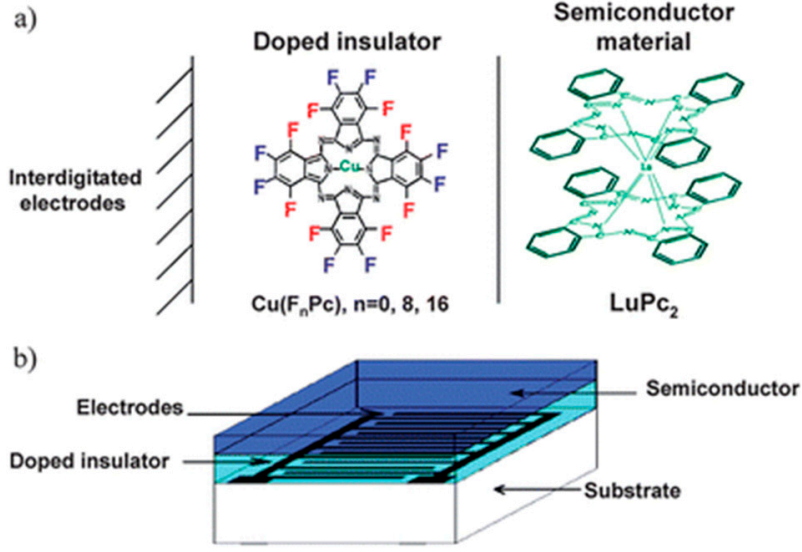

Figure 9. Architecture of the MSDI devices: (a) showing the molecular structure of the phthalocyanine materials; and (b) a schematic view of the organic-based device. Reprinted from [74] with permission from Royal Society of Chemistry.

The sensor performance of MSDI heterostructures based on $\mathrm{LuPc}_{2}$ and $\mathrm{CuPcF}_{16}$ towards $35 \mathrm{ppm}$ of $\mathrm{NH}_{3}$ in an $\mathrm{Ar}$ atmosphere were also compared with that of $\mathrm{CuPcF}_{\mathrm{x}}$ $(\mathrm{x}=0,8,16)$ films [74].

It was found that $\mathrm{LuPc}_{2} / \mathrm{CuPcF}_{8}$ heterostructures had lower sensitivity to $\mathrm{NH}_{3}$ than $\mathrm{LuPc}_{2} / \mathrm{CuPc}$ ones, while $\mathrm{LuPc}_{2} / \mathrm{CuPcF}_{16}$ heterostructures exhibited a completely reversed response, and their sensitivity to ammonia drastically increased. Interestingly, $\mathrm{CuPc} / \mathrm{LuPc}_{2}$ MSDIs showed an increase in current when exposed to ozone $(90 \mathrm{ppb})$ and a decrease in current when exposed to $\mathrm{NH}_{3}$ (35 ppm), indicating the p-type nature of the device. In contrast, the $\mathrm{CuPcF}_{16} / \mathrm{LuPc}_{2}$ MSDIs revealed the opposite trend manifested in the n-type nature of the device [74,102].

In their other work [78], Bouvet et al. fabricated organic heterojunction devices by sequential deposition of $\mathrm{CuPcF}_{16}$ on a glass substrate lithographically patterned with indium tin oxide (ITO) interdigitated electrodes (IDEs) and two different types of porphyrin tapes (pNiDPP and pNiDMP originated from Ni(II) 5,15-(diphenyl)porphyrin (NiDPP) and $\mathrm{Ni}(\mathrm{II})$ 5,15-(dimesityl)porphyrin (NiDMP) monomers, respectively). The investigated devices revealed high response toward ammonia, fast sorption kinetics, stable baseline, and low interference from relative humidity fluctuations. The device based on a $\mathrm{CuPcF}_{16} / \mathrm{pNIDMP}$ bilayer structure exhibited sensitivity about $0.4 \% \mathrm{ppm}^{-1}$ and LOD up to $228 \mathrm{ppb}$.

A summary of the data on the study of sensors based on $\mathrm{MPcF}_{\mathrm{x}}$ films obtained by the PVD method shows that these films are mainly used for the detection of ammonia. It was shown that they exhibited a quite low detection limit, reaching $0.1 \mathrm{ppm}$, and quick response and recovery times. Apart from this, the detection of ammonia can be performed in the presence of carbon dioxide and volatile organic vapors as well as in a humid atmosphere. This makes $\mathrm{MPcF}_{\mathrm{x}}$ films promising candidates for the determination of low concentrations (below 2 ppm) of ammonia as a biomarker of renal diseases $[103,104]$ in exhaled air. The analysis of the literature has shown that, currently, the work on the practical application 
of phthalocyanine films for the determination of biomarker gases is in its infancy, so the development of research in this direction is of great interest for creating a new direction of medical diagnostics.

On the other hand, the bottleneck for using $\mathrm{MPcF}_{\mathrm{x}}$ sensors to detect ammonia or other analytes in complex gas mixtures, including amines and oxidizing gases such as $\mathrm{Cl}_{2}, \mathrm{SO}_{\mathbf{x}}$ and $\mathrm{NO}_{\mathrm{x}}$, is their low selectivity. To overcome this obstacle, it is common practice to create sensor arrays that include sensor layers, which have different sensitivity to the analyzed components of the gas mixture. Currently, no systematic studies of phthalocyanine-based sensor arrays have been conducted. The inclusion of fluorinated metal phthalocyanines in sensor arrays, together with unsubstituted phthalocyanines and/or phthalocyanines with other types of substituents, could open up broad prospects for wider use of these materials.

\subsection{Solution Processed Films}

Films of metal phthalocyanine bearing fluoroalkyl or fluoroaryl substituents, which are deposited by drop cast, spin coating and jet spray techniques, are also widely used as chemiresistive sensors for the detection of toxic gases such as $\mathrm{H}_{2} \mathrm{~S}, \mathrm{NO}_{2}$ or $\mathrm{NH}_{3}$. For example, films of phthalocyanines with various fluoroalkyloxy substituents were studied in a series of works $[52,57,58]$ as active layers of chemiresistive sensors for $\mathrm{NO}_{2}$ detection. Dong et al. [55] prepared conductive films of a metal-free $\mathrm{H}_{2} \mathrm{Pc}\left(\mathrm{OCH}_{2} \mathrm{CF}_{3}\right)_{4}$ derivative (Compound 8, Table 1) by a solution-based quasi-Langmuir-Shäfer (QLS) method, which demonstrated stable and reproducible responses to electron-accepting $\mathrm{NO}_{2}$ gas in the range of $100-500 \mathrm{ppb}$ at room temperature. The authors suggested that the interaction was based on weak intermolecular contacts rather than redox chemistry and the sensor response could primarily be governed by two interior $\mathrm{NH}$ protons of $\mathrm{H}_{2} \mathrm{Pc}$. They also found that no obvious change in current was observed in the reaction of $\mathrm{H}_{2} \mathrm{Pc}\left(\mathrm{OCH}_{2} \mathrm{CF}_{3}\right)_{4}$ with $\mathrm{H}_{2} \mathrm{~S}$ and $\mathrm{NH}_{3}$.

Wang et al. [58] fabricated self-assembled nanostructures on the basis of $\mathrm{H}_{2}\left[\mathrm{Pc}\left(\mathrm{OCH}_{2} \mathrm{C}_{3} \mathrm{~F}_{7}\right)_{8}\right]$ and $\mathrm{Zn}\left[\mathrm{Pc}\left(\mathrm{OCH}_{2} \mathrm{C}_{3} \mathrm{~F}_{7}\right)_{8}\right]$ (Compounds 10, Table 1) by the phase transfer method. Both nanostructures demonstrated a decrease in conductivity upon exposure to electron-accepting $\mathrm{NO}_{2}$ gas (50-900 ppb) and its increase during recovery (Figure 10, left figure), which was consistent with the sensing behavior reported previously for n-type semiconductors. The detection limit was $50 \mathrm{ppb}$ and $100 \mathrm{ppb}$ for the helical microribbons of $\mathrm{H}_{2}\left[\mathrm{Pc}\left(\mathrm{OCH}_{2} \mathrm{C}_{3} \mathrm{~F}_{7}\right)_{8}\right]$ and nanowires of $\mathrm{Zn}\left[\mathrm{Pc}\left(\mathrm{OCH}_{2} \mathrm{C}_{3} \mathrm{~F}_{7}\right)_{8}\right]$, respectively, depending mainly, according to the authors opinion, on their conductivity and ordered morphology of the resulting microstructures.

Later, Sun et al. [57] obtained similar results for thin films of fluoroalkoxy-substituted phthalocyanines with longer perfluoroalkyl chains. They investigated the effect of the method of film formation on their morphology and sensor properties and found that films consisting of more evenly distributed crystallites were formed when deposited in a vacuum compared to the drop-casted films. Vacuum deposition led to an increase in the conductivity of the films and, as a result, to the sensor response to $\mathrm{NO}_{2}$. Both films demonstrated a linear dependence of the sensor response on the $\mathrm{NO}_{2}$ concentration from $100 \mathrm{ppb}$ to $1 \mathrm{ppm}$ with a noticeable increase in sensitivity from $7.54 \% \mathrm{ppm}^{-1}$ for the drop-casted film to $12.05 \% \mathrm{ppm}^{-1}$ for the film deposited in vacuum (Figure 10, right figure).

Phthalocyanines with fluoroaryl substituents were studied as sensing layer for the detection of ammonia and $\mathrm{NO}_{2}$. Kaya et al. [51] prepared films of a CoPc derivative bearing 5-(trifluoromethyl)-2-mercaptopyridine substituents (Compound 12, Table 1) and tested them as sensing layers against low concentrations of $\mathrm{NH}_{3}(0.3-50 \mathrm{ppm})$ by measuring changes in the films' conductivity at different humidities. The first oxidation potential of the prepared $\mathrm{CoPc}$ was higher and the reduction potential was lower compared to similar derivatives without non-fluorinated substituents, which made fluorinated phthalocyanines more sensitive to the reducing analytes. The prepared sensor had a detection limit of $\mathrm{NH}_{3} 0.3 \mathrm{ppm}$, and allowed ammonia to be detected in the presence of VOCs and low concentrations of $\mathrm{CO}_{2}$, but the presence of high $\mathrm{CO}_{2}$ concentrations led to the distortion of the sensor response. 

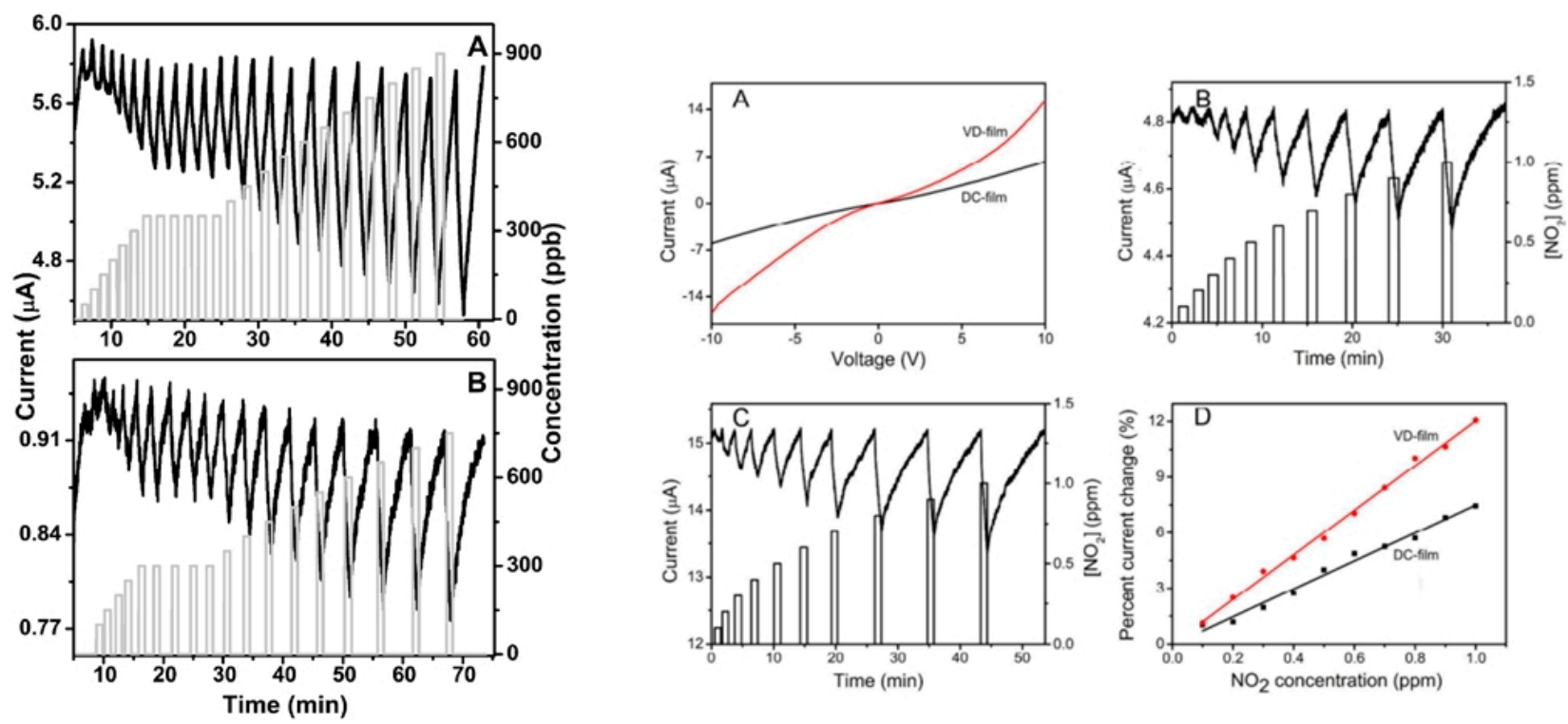

Figure 10. (left) Time-dependent current plots for the microribbons of $\mathrm{H}_{2}\left[\mathrm{Pc}\left(\mathrm{OCH}_{2} \mathrm{C}_{3} \mathrm{~F}_{7}\right)_{8}\right](\mathrm{A})$ and the nanowires of $\mathrm{Zn}\left[\mathrm{Pc}\left(\mathrm{OCH}_{2} \mathrm{C}_{3} \mathrm{~F}_{7}\right)_{8}\right]$ exposed to $\mathrm{NO}_{2}$ at varied concentration (B). Reprinted from [58] with permission from Elsevier. (right) I-V curves measured on the drop-casted (DC) film and the film deposited in vacuum (VD) (A); the time-dependent current plot of sensor as a function of the $\mathrm{NO}_{2}$ concentration in $\mathrm{N}_{2}$ atmosphere for the DC film (B), and the VD film (C); and the sensor response varies linearly with $\mathrm{NO}_{2}$ concentration of the DC film and the VD film (D). Reprinted from [57] with permission from Royal Society of Chemistry.

Duan et al. [52] tested films of a series of tetrasubstituted cobalt and metal-free phthalocyanine derivatives with 4-trifluoromethylphenoxy groups in peripheral $\left(\mathrm{MPc}\left[\beta-\mathrm{O}\left(4-\mathrm{CF}_{3}-\mathrm{Ph}\right)_{4}\right]\right)$ and non-peripheral $\left(\mathrm{MPc}\left[\alpha-\mathrm{O}\left(4-\mathrm{CF}_{3}-\mathrm{Ph}\right)_{4}\right]\right)$ positions of phthalocyanine ring (Compounds 6, Table 1) as sensors towards $\mathrm{NO}_{2}, \mathrm{NH}_{3}$ and $\mathrm{H}_{2} \mathrm{~S}$. They showed that the LOD of $\mathrm{NO}_{2}$ increased in the order of $\mathrm{CoPc}\left[\beta-\mathrm{O}\left(4-\mathrm{CF}_{3}-\mathrm{Ph}\right]\right)_{4}(3 \mathrm{ppb})<\mathrm{H}_{2} \mathrm{Pc}\left[\beta-\mathrm{O}\left(4-\mathrm{CF}_{3}-\mathrm{Ph}\right)\right]_{4}(30 \mathrm{ppb})$ $<\mathrm{CoPc}\left[\alpha-\mathrm{O}\left(4-\mathrm{CF}_{3}-\mathrm{Ph}\right)\right]_{4}(198 \mathrm{ppb})<\mathrm{H}_{2} \mathrm{Pc}\left[\alpha-\mathrm{O}\left(4-\mathrm{CF}_{3}-\mathrm{Ph}\right)\right]_{4}(250 \mathrm{ppb})$. The maximal sensitivity of a $\mathrm{CoPc}\left[\beta-\mathrm{O}\left(4-\mathrm{CF}_{3}-\mathrm{Ph}\right]\right)_{4}$ film to $\mathrm{NO}_{2}$ was explained by the governed role of Co- $\mathrm{NO}_{2}$ coordination strength and the best conductivity of the films of this phthalocyanine derivative. $\mathrm{CoPc}\left[\beta-\mathrm{O}\left(4-\mathrm{CF}_{3}-\mathrm{Ph}\right]\right)_{4}$ films were found to exhibit the highest sensitivity and the lowest sensor response to $\mathrm{NH}_{3}$ and $\mathrm{H}_{2} \mathrm{~S}$. It was interesting that, upon interaction with oxidizing $\mathrm{NO}_{2}$, all four sensors exhibited a decrease in current, behaving as n-type semiconductors. However, a positive current response was observed for $\mathrm{CoPc}\left[\beta / \alpha-\mathrm{O}\left(4-\mathrm{CF}_{3}-\mathrm{Ph}\right)_{4}\right]$ towards electron-donating $\mathrm{NH}_{3}$, resulting from n-type charge carriers, while a negative current response was observed for $\mathrm{H}_{2} \mathrm{Pc}\left[\beta / \alpha-\mathrm{O}\left(4-\mathrm{CF}_{3}-\mathrm{Ph}\right)_{4}\right]$ as a p-type material. According to the authors, that behavior was attributed to the lower levels of LUMO energies in cobalt phthalocyanines compared to in the metal-free ones.

The analysis of the sensor properties of metal phthalocyanines with fluoroalkyl and fluoroaryl substituents shows that their sensor performance is determined not only by the type of substituents, but also by their position in phthalocyanine rings.

Apart from monophthalocyanines, bis- and tris(phthalocyaninato) rare earth complexes are also used for application in chemiresistive sensors, however the works on investigation of sensor properties of fluorinated bis- and tris-phthalocyanines are sporadic. Zhao et al. [82] studied the solution-based films of two ambipolar (p-fluoro)phenoxy substituted tris(phthalocyaninato) rare earth semiconductors with gadolinium $\mathrm{Gd}_{2}\left[\mathrm{Pc}(\mathrm{OPhF})_{8}\right]_{3}$ and terbium $\mathrm{Tb}_{2}\left[\mathrm{Pc}(\mathrm{OPhF})_{8}\right]_{3}$ (Compounds 11, Table 1). Both films prepared by a quasiLangmuir-Shäfer (QLS) method revealed ambipolar semiconductor nature with a p-type response toward ammonia and n-type response toward nitrogen dioxide. The ambipolar behavior was associated not only with suitable HOMO and LUMO levels, but also with different electronic induction effects of the investigated gases. Apart from this, the films 
of $\mathrm{Tb}_{2}\left[\mathrm{Pc}(\mathrm{OPhF})_{8}\right]_{3}$ having J-type (edge-to-edge) packing mode and, as a consequence, the larger specific surface area, displayed noticeably higher sensor response to both $\mathrm{NH}_{3}$ and $\mathrm{NO}_{2}$, compared to the films of $\mathrm{Gd}_{2}\left[\mathrm{Pc}(\mathrm{OPhF})_{8}\right]_{3}$ with a stronger intermolecular $\pi-\pi$ stacking in the $\mathrm{H}$-type (face-to-face) packing mode. $\mathrm{Tb}_{2}\left[\mathrm{Pc}(\mathrm{OPhF})_{8}\right]_{3}$ films exhibited stable and reversible response to $\mathrm{NH}_{3}$ in the concentration range of 1-25 ppm with the LOD as low as $0.15 \mathrm{ppm}$.

Thus, the literature analysis shows that films of metal phthalocyanines bearing fluoroalkyl or fluoroaryl substituents, which are deposited by solution methods, are much less studied compared to $\mathrm{MPcF}_{\mathrm{x}}$ ones. At the same time, the chemical versatility of substituted phthalocyanines allows the introduction of various substituents, which can allow for a wide variation in the sensitivity of compounds to analytes of different nature. Moreover, the better solubility of MPcs with fluoroalkyl or fluoroaryl substitutes compared to $\mathrm{MPcF}_{\mathrm{x}}$ derivatives provides the ability to produce inks and to use inkjet printing, which offers several advantages over other methods for deposition of thin films, e.g., patterning capability, reduction in waste, high speed, low cost, applicability to large areas and flexible substrates.

\subsection{Hybrid Materials with Carbon Nanotubes}

It is known that the synergistic combination of the properties of phthalocyanines and carbon nanomaterials leads to the improvement of various properties of hybrid materials [105]. Along with other phthalocyanines, the examples of application of their fluorinated derivatives in gas sensors are also described in the literature [106]. Sharma and co-authors $[63,64,83-85]$ prepared hybrid materials via non-covalent functionalization of acid-treated multi-walled (MWCNTs-COOH) and single-walled (SWCNTs-COOH) with $\mathrm{MPcF}_{16}$ derivatives (Figure 11, left image).
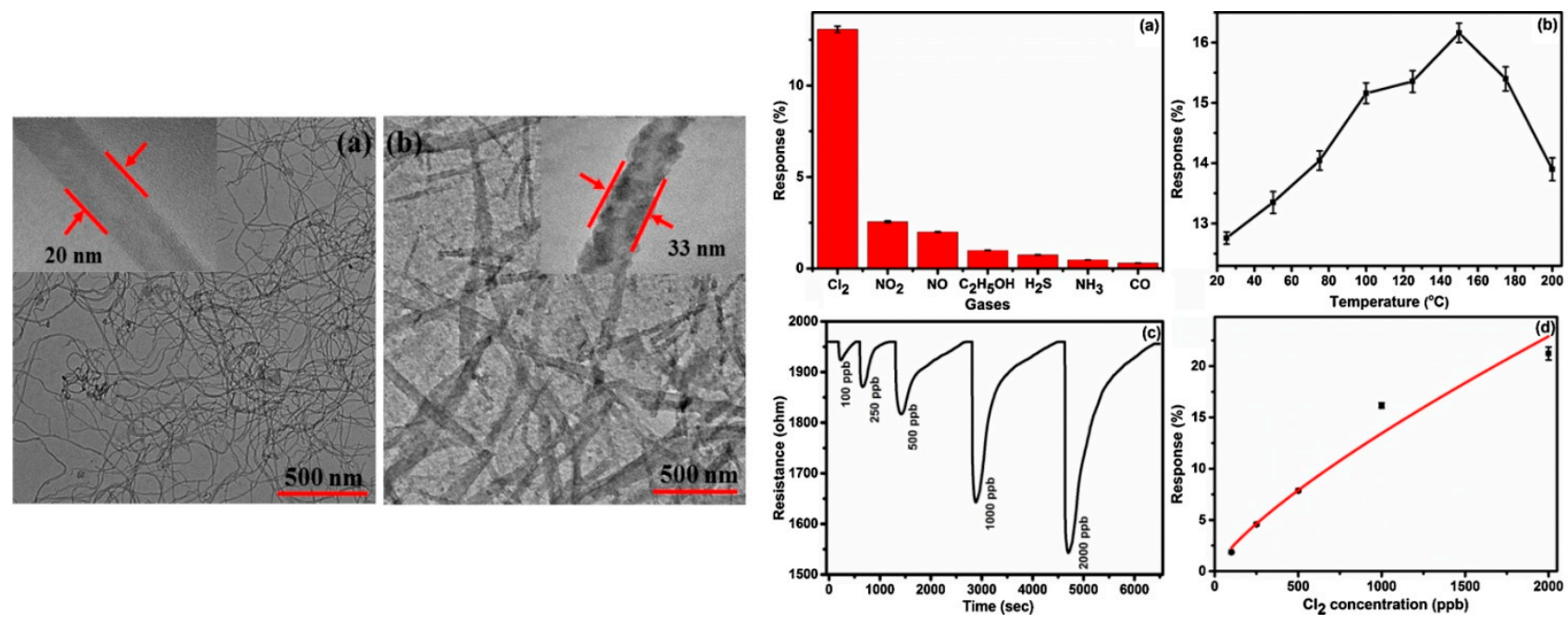

Figure 11. (left) TEM images of MWCNTs-COOH (a) and $\mathrm{ZnPcF}_{16} / \mathrm{MWCNTs}-\mathrm{COOH}$ (b) hybrids. (right) (a) Response histogram of a $\mathrm{ZnPcF}_{16} / \mathrm{MWCNTs}-\mathrm{COOH}$ sensor for $1 \mathrm{ppm}$ of $\mathrm{Cl}_{2}, \mathrm{NO}_{2}, \mathrm{NO}, \mathrm{C}_{2} \mathrm{H}_{5} \mathrm{OH}, \mathrm{H}_{2} \mathrm{~S}, \mathrm{NH}_{3}$ and $\mathrm{CO}$ at room temperature; (b) Sensor response as a function of temperature for 1 ppm of $\mathrm{Cl}_{2}$ concentration; (c) Response curves of the sensor for different doses of $\mathrm{Cl}_{2}$ at $150{ }^{\circ} \mathrm{C}$; (d) Variation in the response of sensor with $\mathrm{Cl}_{2}$ concentration. Reprinted from [64] with permission from Elsevier.

The sensing layers of $\mathrm{ZnPcF}_{16} / \mathrm{MWCNTs-COOH}$ and $\mathrm{CuPcF}_{16} / \mathrm{SWCNTs-COOH}$ hybrids were shown to have high sensitivity to $\mathrm{Cl}_{2}$ with a detection limit of $0.06 \mathrm{ppb}$ and $0.27 \mathrm{ppb}$, respectively, and excellent recovery and reversibility (Table 2) $[63,64,85]$. The response was found to be $21.28 \%$ for $2 \mathrm{ppm}$ of $\mathrm{Cl}_{2}$ with a response time of $14 \mathrm{~s}$ (Figure 11, right) for the hybrid material with $\mathrm{ZnPcF}_{16}$.

To investigate how central metal affects the interactions between the phthalocyanine and single-walled carbon nanotubes and gas sensing properties of the prepared hybrids, the same group of authors investigated $\mathrm{MPcF}_{16}$ with $\mathrm{M}=\mathrm{Co}, \mathrm{Zn}$, and $\mathrm{Cu}$ [85]. The results 
demonstrated that the response decreased in the order of $\mathrm{Co}>\mathrm{Zn}>\mathrm{Cu}$, indicating that the central metal ions play an important role in the sensitivity to $\mathrm{Cl}_{2}$. $\mathrm{CoPcF}_{16} / \mathrm{SWCNTs}-$ $\mathrm{COOH}$ sensor exhibited the highest sensitivity ( $82 \%$ for 2 ppm with LOD of $0.04 \mathrm{ppb}$ ), excellent reproducibility and selectivity towards chlorine (Figure 12).
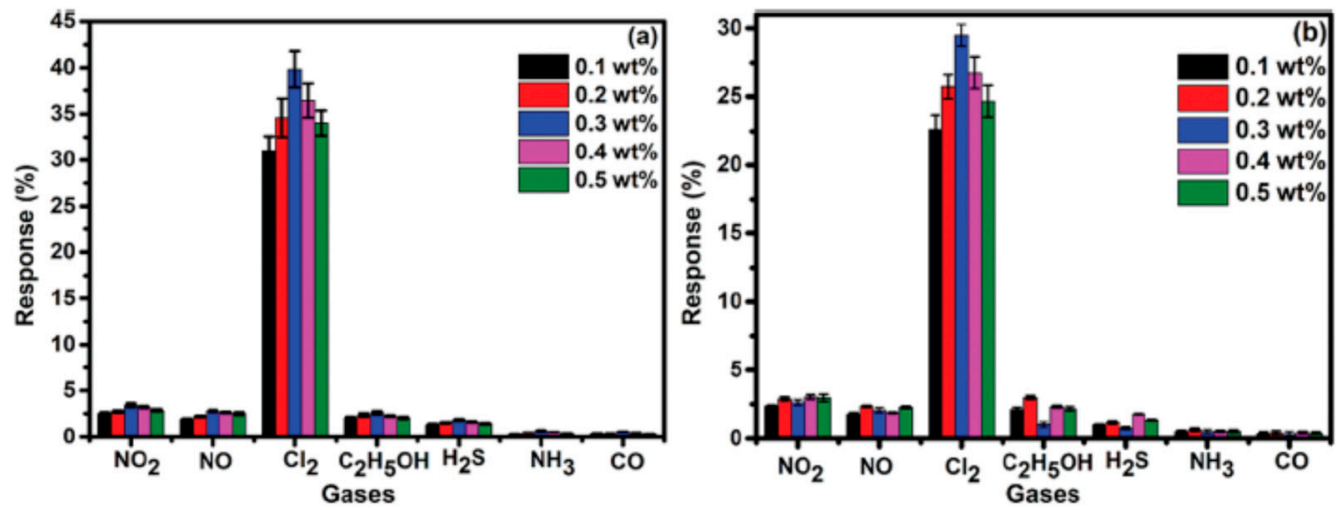

Figure 12. Selectivity histogram of $\mathrm{CoPcF} 16 / \mathrm{SWCNTs}-\mathrm{COOH}$ (a) and $\mathrm{ZnPcF} 16 / \mathrm{SWCNTs}-\mathrm{COOH}$ (b) hybrids for $500 \mathrm{ppb}$ of $\mathrm{NO}_{2}, \mathrm{NO}, \mathrm{Cl}_{2}, \mathrm{C}_{2} \mathrm{H}_{5} \mathrm{OH}, \mathrm{H}_{2} \mathrm{~S}, \mathrm{NH}_{3}$ and $\mathrm{CO}$ at room temperature [88].

In our recent paper [86], the sensor response of the layers of hybrid materials of single-walled carbon nanotubes noncovalently functionalized with a fluoroalkyl substituted zinc(II) phthalocyanine (Compound 7, Table 1) was compared with that of the similar hybrid modified with the nonfluorinated analogue to reveal the role of fluorinated substituents. It was found that the introduction of long fluoroalkyl substituents led to a decrease in the functionalization degree; the amount of $\mathrm{ZnPc}-\mathrm{CF}$ molecules adsorbed on SWCNT walls was 1.5 times less than in the case of the hybrid modified with the nonfluorinated phthalocyanine $(\mathrm{ZnPc}-\mathrm{CH})$. As a result, the sensitivity of $\mathrm{ZnPc}-\mathrm{CF}$-based sensor to ammonia was two times less than in the case of SWCNT/ZnPc-CH, while its sensor response was more stable in a humid atmosphere (RH 70\%) (Figure 13).
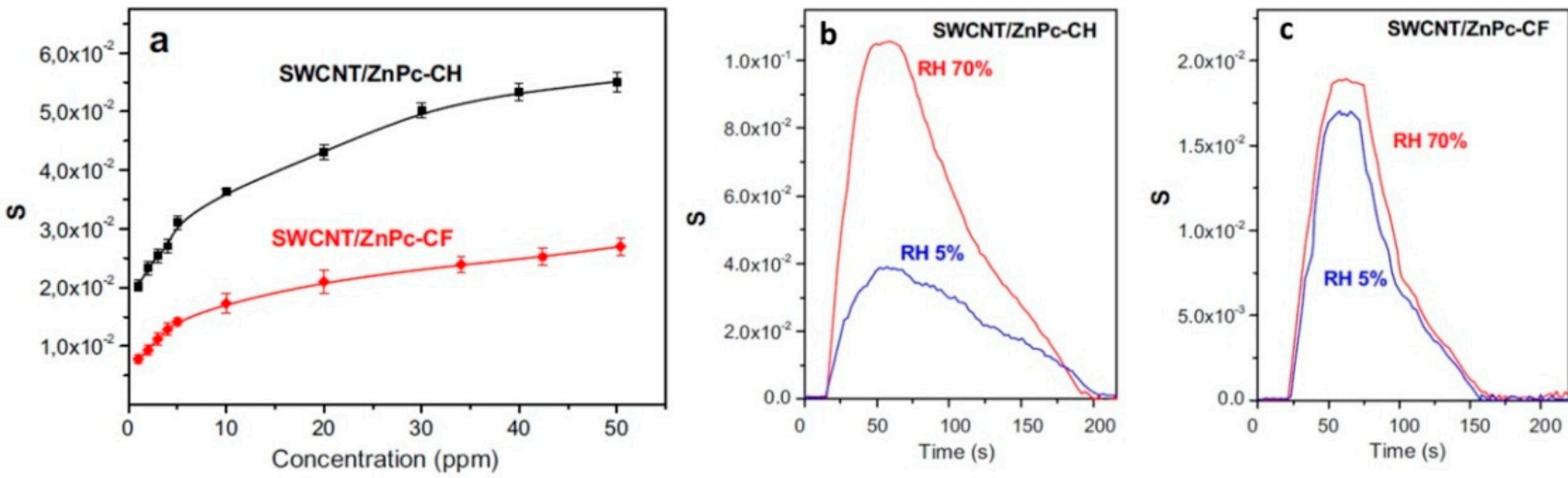

Figure 13. Dependence of the sensor response of SWCNT/ZnPc-CH and SWCNT/ZnPc-CF layers on ammonia concentration from 1 to $50 \mathrm{ppm}$ (a). Sensor response of SWCNT/ZnPc-CH (b) and SWCNT/ZnPc-CF (c) hybrid layers to ammonia (10 ppm) measured at RH 5\% and 70\%. Reprinted from [86] with permission from Springer Nature.

These few examples show that hybrids of fluorinated phthalocyanines with carbon nanomaterials (e.g., SWCNT, MWCNT and graphene derivatives) are also promising materials as active layers of chemiresistive layers. The use of hybrid materials leads to an increase in the conductivity of the sensitive layers, which avoids the use of expensive highly sensitive electrometers, but the selectivity of hybrid-based sensors becomes less than in the case of pure phthalocyanine films. At the moment, the limited number of studied hybrid materials with fluorinated phthalocyanines does not allow us to make any conclusions 
about any correlations between their structure and sensor properties. Expanding the range of fluorinated substituents in the phthalocyanine ring and obtaining hybrids by covalent functionalization of nanotubes with fluorinated phthalocyanines may be a further way to develop this scientific direction and improve the performance of sensor devices.

\section{Other Types of Chemical Sensors}

Apart from the sensors with electrical sensor response, the films of fluorinated metal phthalocyanines are utilized in other types of chemical sensors. Among them, the most popular are optical sensors and quartz crystal microbalance (QCM) ones (Table 3).

Table 3. Main characteristics of optical and QCM sensors on the basis of fluorinated metal phthalocyanines.

\begin{tabular}{|c|c|c|c|c|c|c|}
\hline Active Layer & Sensor Type & Analyte & $\begin{array}{l}\text { Investigated } \\
\text { Range, Ppm }\end{array}$ & LOD, Ppm & Recovery Time, $S$ & Ref. \\
\hline $\begin{array}{c}\mathrm{MPcF}_{16} \\
(\mathrm{M}=\mathrm{Zn}, \mathrm{Co}, \mathrm{Cu}, \mathrm{Ni})\end{array}$ & SPR & $\mathrm{NH}_{3}$ & 100,200 ppm & $\mathrm{n} / \mathrm{a}$ & $15-30$ & [96] \\
\hline $\mathrm{CoPcF}_{16}$ & TIRE & $\mathrm{NH}_{3}$ & 50-1000 & $\mathrm{n} / \mathrm{a}$ & $\mathrm{n} / \mathrm{a}$ & [107] \\
\hline $\begin{array}{l}\mathrm{ZnPc}\left(\mathrm{OCH}_{2} \mathrm{CF}_{2} \mathrm{CHF}_{2}\right)_{8} \\
(\text { Compound 13, Table 1) }\end{array}$ & TIRE & Trimethylamine & $10-300$ & 20 & $\mathrm{n} / \mathrm{a}$ & [56] \\
\hline $\mathrm{MPcF}_{16},(\mathrm{M}=\mathrm{Zn}, \mathrm{Cu})$ & QCM & Toluene & 500 & $\mathrm{n} / \mathrm{a}$ & $\mathrm{n} / \mathrm{a}$ & [108] \\
\hline $\begin{array}{c}\text { TiLR }_{4} \\
\text { TiLR }_{8} \\
\text { (Compounds 14, Table 1) } \\
\text { (See Section 4.2.) }\end{array}$ & QCM & $\begin{array}{c}\mathrm{MeOH} \\
\text { n-Propanol } \\
\text { etylacetate } \\
\text { triethylamine } \\
\text { acetonitrile } \\
\text { DMMP } \\
\text { n-heptane } \\
\text { ethyl benzene } \\
\text { toluene o-xylene } \\
\mathrm{C}_{2} \mathrm{Cl}_{4} \\
\text { chlorobenzene }\end{array}$ & $\begin{array}{c}1000-5000 \\
130-650 \\
900-4500 \\
10-50 \\
950-4700 \\
3-15 \\
380-1900 \\
70-350 \\
240-1200 \\
40-200 \\
150-730 \\
100-480 \\
\end{array}$ & $\mathrm{n} / \mathrm{a}$ & $\mathrm{n} / \mathrm{a}$ & [54] \\
\hline Compounds 15, Table 1 & QCM & $\begin{array}{c}\text { dichloromethane } \\
\text { (DCM), } \\
\text { chloroform, tetra- } \\
\text { chloroetylene, } \\
\text { chlorobenzene, } \\
\text { toluene, o-xylene, } \\
\text { p-xylene }\end{array}$ & 0.1-300 (for DCM) & $\begin{array}{l}\text { For Compound } \\
\text { 15c (Table 1): } \\
5 \text { (for DCM) } \\
0.05 \text { (for } \\
\text { o-xylene) }\end{array}$ & 90 & [109] \\
\hline $\begin{array}{l}\text { Compounds described in } \\
\text { Section } 4.2 \text {. }\end{array}$ & $\begin{array}{l}\text { QCM } \\
\text { SAW }\end{array}$ & DMMP & 1.5-12 ppm & $\begin{array}{c}0.6 \text { (for } 1 b) \\
0.8 \text { (for } 2 c \text {, see } \\
\text { Section } 4.2 .)\end{array}$ & 40 (for $1 b)$ & {$[110]$} \\
\hline Compounds 16, Table 1 & QCM & Humidity & 10-90\% RH & $\mathrm{n} / \mathrm{a}$ & $\sim 60$ & [111] \\
\hline Compounds 15, Table 1 & QCM & $\begin{array}{c}\text { methanol } \\
\text { propanol } \\
\text { acetonitrile } \\
\text { ethyl acetate } \\
\text { toluene } \\
\text { ethylbenzene } \\
\text { o-xylene } \\
\text { chlorobenzene } \\
\text { chloroform } \\
\text { trichloroethylene } \\
\text { n-heptane } \\
\text { trimethylamine }\end{array}$ & $\begin{array}{c}1000-5000 \\
131-653 \\
944-4719 \\
902-4509 \\
243-1213 \\
69-345 \\
40-198 \\
95-477 \\
2145-10,726 \\
788-3939 \\
385-1927 \\
721-3606\end{array}$ & $\begin{array}{c}144 \\
34 \\
58 \\
36 \\
13 \\
3 \\
2 \\
3 \\
10,030 \\
60 \\
37\end{array}$ & $\mathrm{n} / \mathrm{a}$ & [33] \\
\hline
\end{tabular}

\subsection{Optical Sensors}

Surface plasmon resonance (SPR) [96] and spectroscopic ellipsometry in total internal reflection configuration (TIRE) [56] were known to be used as optical techniques to study the sensor response of thin layers of fluorinated phthalocyanine derivatives. In our previous work [96], an SPR technique in the Kretschmann configuration was utilized for 
the investigation of the sensor response of $\mathrm{MPcF}_{16}(\mathrm{M}=\mathrm{Zn}, \mathrm{Co}, \mathrm{Cu}, \mathrm{Ni})$ films deposited on gold-coated glass substrates to ammonia at 100 and $200 \mathrm{ppm}$. This is a well-known optical method for real-time monitoring of various molecular interactions (binding), their mechanisms and kinetics. The sensor response is based on the changes in the refractive index of the sensing layer, caused by the binding between an analyte in gas or solution, due to the generation of the surface plasmons at a metal/dielectric interface in a specific condition. The typical SPR curves, which are the dependence of reflected light intensity on the internal angle of incidence, are shown in Figure 14 (left graph) for the pure gold-coated substrate (a), the thin film of as-deposited $\mathrm{CuPcF}_{16}(\mathrm{~b})$, and the film exposed to ammonia (c). The kinetic curves of the sensor response of the $\mathrm{MPcF}_{16}$ thin films to $\mathrm{NH}_{3}(100$ and 200 ppm) are presented in Figure 14 (right graph).
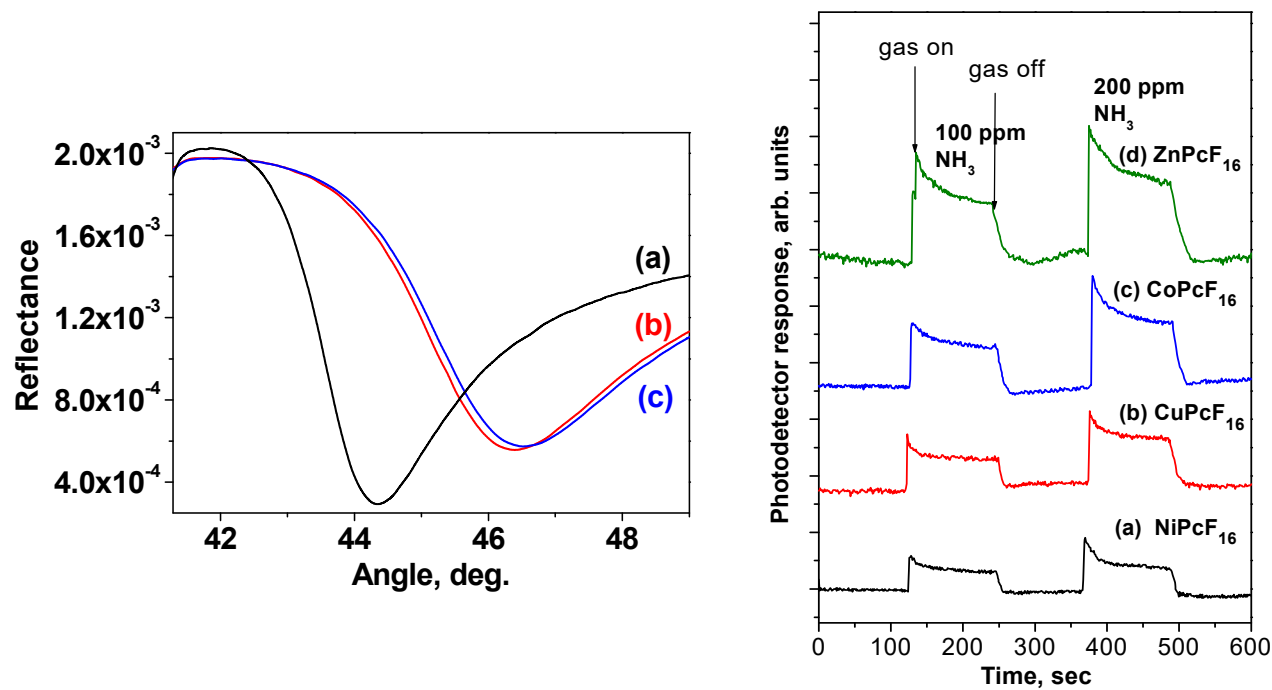

Figure 14. (left) Surface plasmon resonance curves for (a) pure gold-coated substrate; (b) gold/asdeposited $\mathrm{CuPcF}_{16}$ film; and (c) gold $/ \mathrm{CuPcF}_{16}$ exposed by $\mathrm{NH}_{3}$ gas (200 ppm). (right) SPR response curves of $\mathrm{MPcF}_{16}$ thin films toward gaseous $\mathrm{NH}_{3}$ (100 ppm and $200 \mathrm{ppm}$, respectively): (a) $\mathrm{NiPcF}_{16}$, black; (b) $\mathrm{CuPcF}_{16}$, red; (c) $\mathrm{CoPcF}_{16}$, blue; (d) $\mathrm{ZnPcF}_{16}$, green. The SPR response curves were recorded using the wavelength of $633 \mathrm{~nm}$ (He-Ne laser) at a fixed angle of incidence $\Theta=44.2$. Reprinted from [96] with permission from Elsevier.

It was found that the sensor response decreased in the order $\mathrm{ZnPcF}_{16}>\mathrm{CoPcF}_{16} \geq$ $\mathrm{CuPcF}_{16}>\mathrm{NiPcF}_{16}$. To obtain more insight into the interplay between microscopic structure and sensor response of the films, the authors carried out the DFT calculations of the binding energies of phthalocyanines with analyte molecules, and measured a shift of the selected IR bands in $\mathrm{MPcF}_{16}$ spectra during the exposure to gaseous ammonia. It was shown that the energies of $\mathrm{MPcF}_{16} \cdot \mathrm{NH}_{3}$ complex formation, red shifts of wavenumbers of some IR bonds, and refractive index changes appearing upon exposure ammonia correlated well with each other.

A total internal reflection ellipsometry method (TIRE) was also employed as an optical technique to examine $\mathrm{CoPcF}_{16}$ as an optical active layer for the detection of ammonia [107] and zinc phthalocyanine with fluorinated n-propanol in peripheral positions (Compound 13, Table 1) as an active layers for the detection of trimethylamine [56]. TIRE combines the spectroscopic ellipsometry platform with the Kretschmann's SPR geometry [112]. The experimental setup and principles of this method are described in more detail in earlier publications $[113,114]$. The spectrum of $\Psi(\lambda)$, which exhibits the amplitude ratio of $A_{p} / A_{s}$ between $p$ - and s-components of polarized light, is similar to the conventional SPR curve, while the spectrum of $\Delta(\lambda)$ is associated with the phase shift between p-and s-components. According to Arwin's modelling [112], the position of the sharp drop in the $\Delta(\lambda)$ spectrum is about 10 times more sensitive to adsorption of analyte molecules than the $\Psi(\lambda)$ spectrum. 
TIRE spectra of the spun films of $\mathrm{ZnPc}\left(\mathrm{OCH}_{2} \mathrm{CF}_{2} \mathrm{CHF}_{2}\right)_{8}$ (Compound 13, Table 1), and its nonfluorinated analogue $\mathrm{ZnPc}\left(\mathrm{OCH}_{2} \mathrm{CH}_{2} \mathrm{CH}_{3}\right)_{8}$, before and after exposure to trimethylamine are shown in Figure 15 as an example [56]. The change in the $\Delta(\lambda)$ spectrum is much more pronounced than in the case of the $\Psi(\lambda)$ spectrum. The change in the optical parameters (Table 4) of the $\mathrm{ZnPc}\left(\mathrm{OCH}_{2} \mathrm{CF}_{2} \mathrm{CHF}_{2}\right)_{8}$ film and as a consequence its optical response was found to be higher than for the film of nonfluorinated derivative. It was shown that, similarly to the case of chemiresistive sensors, the optical response was higher in the case of derivatives bearing fluorinated substituents, and the limit of trimethylamine detection was $20 \mathrm{ppm}$.
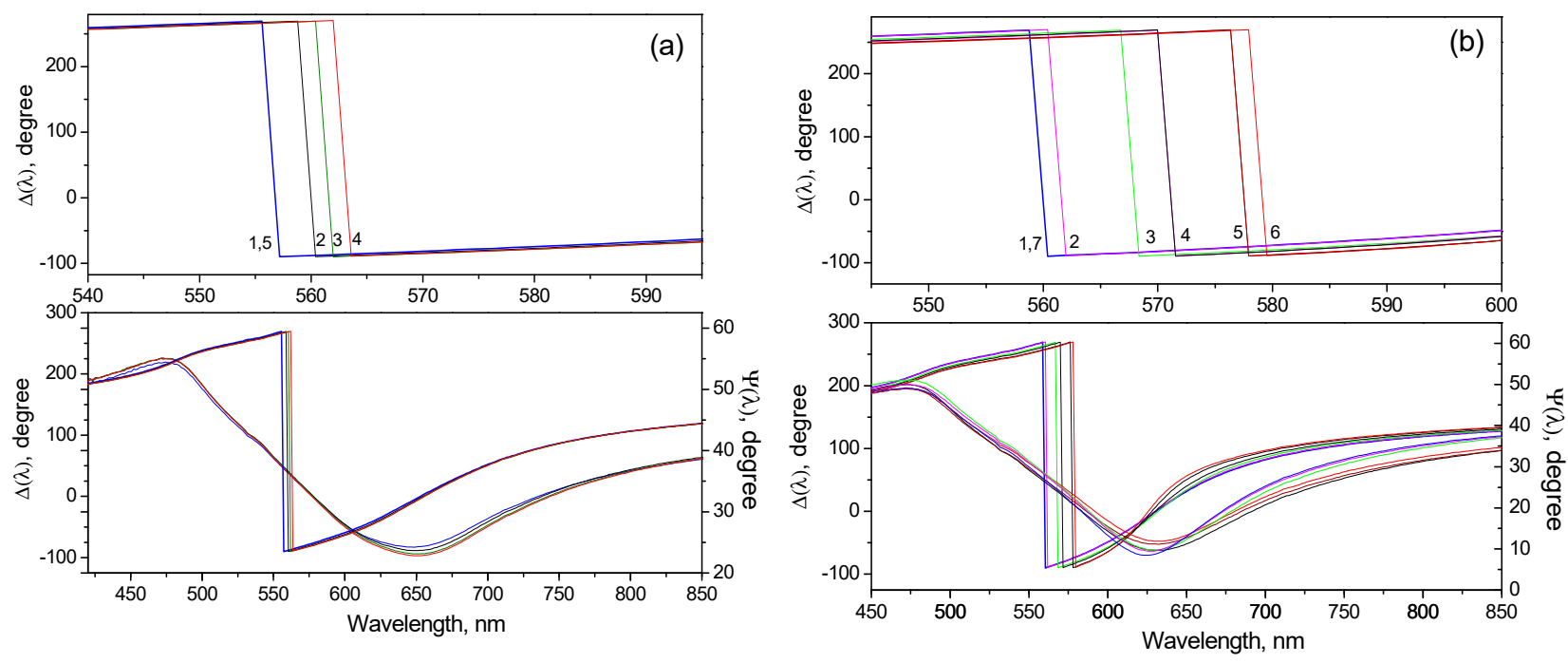

Figure 15. (a) $\Psi(\lambda)$ and $\Delta(\lambda)$ TIRE spectra: (a) $\mathrm{ZnPc}\left(\mathrm{OCH}_{2} \mathrm{CH}_{2} \mathrm{CH}_{3}\right)_{8}$ in air (curve 1); after injection of trimethylamine 200, 250 and 300 ppm (curves 2, 3 and 4, respectively); after flushing with air (curve 5); (b) the film of $\mathrm{ZnPc}\left(\mathrm{OCH}_{2} \mathrm{CF}_{2} \mathrm{CHF}_{2}\right)_{8}$ in air (curve 1); after injection of trimethylamine 20, 60, 100, 250 and 300 ppm (curves 2-6, respectively); after flushing with air (curve 7). Enlarged sections of $\Delta(\lambda)$ spectra are shown on the top. Reprinted from [56] with permission from Elsevier.

Table 4. Thickness (d), refractive indexes (n) and extinction coefficients (k) for $\mathrm{ZnPc}\left(\mathrm{OCH}_{2} \mathrm{CH}_{2} \mathrm{CH}_{3}\right)_{8}$ and $\mathrm{ZnPc}\left(\mathrm{OCH}_{2} \mathrm{CF}_{2} \mathrm{CHF}_{2}\right)_{8}$ films, before and after interaction with trimethylamine [56].

\begin{tabular}{|c|c|c|c|c|}
\hline & \multicolumn{2}{|c|}{$\mathrm{ZnPc}\left(\mathrm{OCH}_{2} \mathrm{CH}_{2} \mathrm{CH}_{3}\right)_{8}$} & \multicolumn{2}{|c|}{$\mathrm{ZnPc}\left(\mathrm{OCH}_{2} \mathrm{CF}_{2} \mathrm{CHF}_{2}\right)_{8}$} \\
\hline & Initial Film & $\begin{array}{l}\text { After Exposure with } \\
\text { Trimethylamine }\end{array}$ & Initial Film & $\begin{array}{l}\text { After Exposure with } \\
\text { Trimethylamine }\end{array}$ \\
\hline$n(\lambda=633 \mathrm{~nm})$ & 1.33 & 1.33 & 1.32 & 1.34 \\
\hline$k(\lambda=633 \mathrm{~nm})$ & 0.15 & 0.15 & 0.19 & 0.21 \\
\hline$d, \mathrm{~nm}$ & 19.4 & 19.7 & 18.9 & 20.9 \\
\hline
\end{tabular}

The authors of [105] used a TIRE method to compare the sensor response of $\mathrm{CoPcF}_{16}$ films deposited at different substrate temperatures to ammonia. They found that the films deposited at a substrate temperature of $220^{\circ} \mathrm{C}$ exhibited the higher response, due to their greater roughness and more developed surface [96,107].

In comparison to chemiresistive sensors, the optical ones on the basis of fluorinated MPcs exhibit less sensitivity to investigated analytes. One of the possibilities for improving their sensitivity is related to their supramolecular organization on the substrate surface. For example, the preparation of nanostructured films in the form of nanofibers and nanowires with a developed surface area [115] would increase the sensitivity of the sensor layers.

\subsection{Quartz Crystal Microbalance Sensors}

One more method, in which fluorinated phthalocyanines are used as sensing materials, is quartz crystal microbalance $(\mathrm{QCM})$. QCM is an analytical tool sensitive to mass 
changes on the surface. Its principle of operation is based on the change in the mass of the active substance on the surface of the converter during gas adsorption, which leads to a change in the resonant frequency of the crystal in accordance with the Sauerbrey's equation [116]. QCM sensors based on phthalocyanines, including fluorinated ones, were used for detection of various analytes. For example, Kumar and co-workers [108] compared the sensitivity of $\mathrm{MPcF}_{16}(\mathrm{M}=\mathrm{Cu}, \mathrm{Zn})$-coated QCMs to toluene with that of the corresponding unsubstituted and tert-butyl-substituted derivatives. It was shown that the introduction of fluorine atoms decreased the sensitivity of metal phthalocyanines to toluene.

Harbeck et al. [109] tested a series of metal phthalocyanines bearing fluoroalkyloxy substituents (Compounds 15, Table 1), which exhibited a good sensor performance toward some volatile organic compounds (VOCs), both gaseous and dissolved in water. All sensors demonstrated reversible sensor response to VOCs at room temperature and a linear dependence on analyte concentrations (Figure 16).
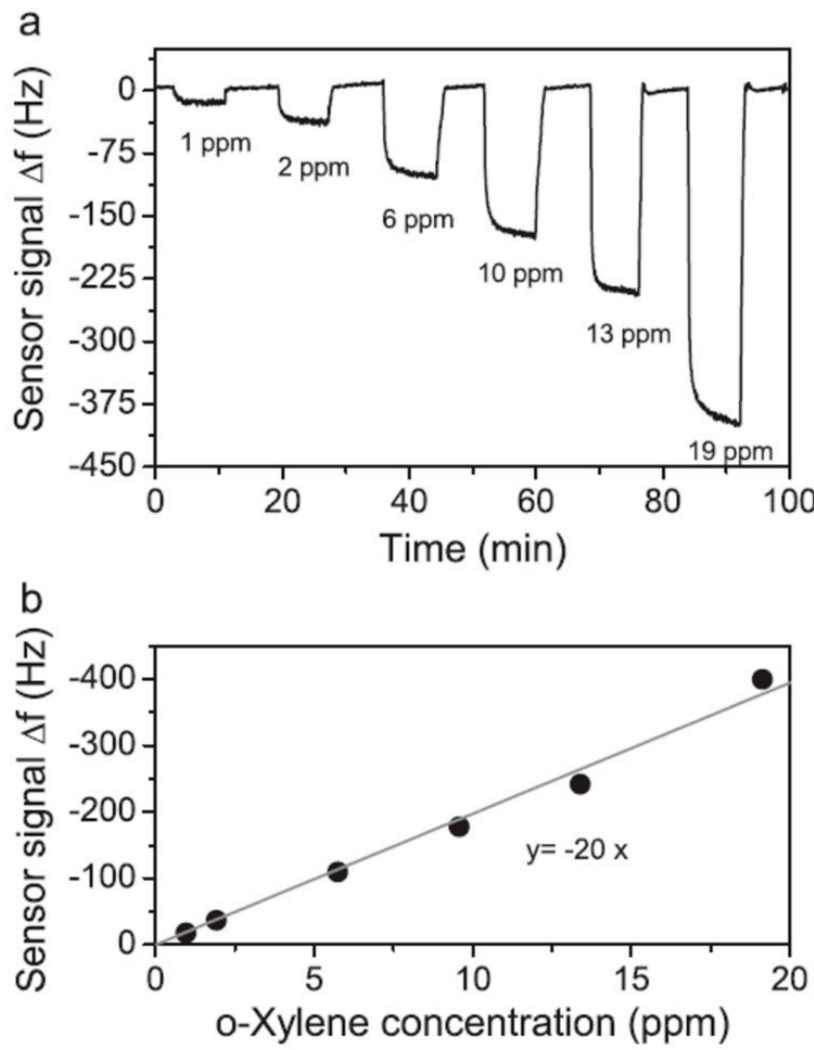

Figure 16. Transient signal of a QCM sensor with the film of octasubstituted CuPc derivative (Compound 15c, Table 1) during exposure to samples containing o-xylene in concentration between 1 and 20 ppm (a) and resulting calibration curve (b). Reprinted from [109] with permission from Elsevier.

It was shown that the sensor response increased for all materials in the order dichloromethane $<$ chloroform $<$ toluene $<$ chlorobenzene $<$ tetrachloroethylene $<$ p-xylene $<$ o-xylene. The maximal response was observed for octasubstituted phthalocyanine (Compound 15c, Table 1) with the LOD of dichloromethane of $5 \mathrm{ppm}$ and the LOD of o-xylene of $0.05 \mathrm{ppm}$.

Phthalocyanines with similar fluoroalkyloxy-substituents as well as with fluoroaryloxygroups were studied in QCM sensors toward another set of volatile organic compounds (methanol, propanol, acetonitrile, ethyl acetate, toluene, o-xylene, chlorobenzene, eriethylamine etc.) [33]. Octasubstituted $\mathrm{NiPc}$ and $\mathrm{ZnPc}$ with fluoroalkyloxy groups, which increase their polarity and polarizability, demonstrated the best sensor performance and were shown to be very sensitive to polar compounds such as ethyl acetate or acetoni- 
trile. LODs, except for methanol, were below $100 \mathrm{ppm}$, and for some aromatic VOCs, even below $10 \mathrm{ppm}$.

Similar tetra- and octasubstituted titanium phthalocyanines with -O- $\mathrm{CH}_{2} \mathrm{CF}_{2} \mathrm{CHF}_{2}$ groups in the benzene rings and different axial substituents (Compounds 14, Table 1; Figure 17(1)) were tested as QCM sensors toward dimethyl methylphosphonate (DMMP), $\mathrm{MeOH}, \mathrm{n}$-propanol, etyl acetate, triethylamine, acetonitrile and their mixtures [54]. The principal component analysis (PCA) was used to treat the data on investigation of their sensor response (Figure 17(2)). It was shown that, along with substituents in the phthalocyanine ring, the type of the axial ligand had a pronounced effect on both sensor response and selectivity to investigated analytes. The best value of the sensor response to dimethyl methylphosphonate and fast kinetics were found for $1 \mathrm{f}$ and $2 \mathrm{f}$ compounds (Figure 17(1)). If and $1 \mathrm{~g}$, as well as $2 \mathrm{e}$ and $2 \mathrm{f}$, derivatives exhibited the best sensor response to triethylamine.

(1)

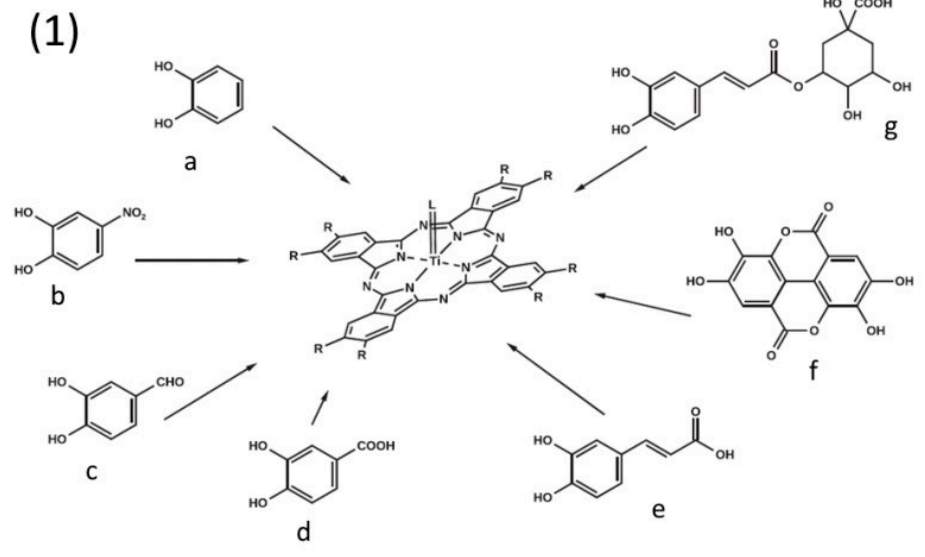

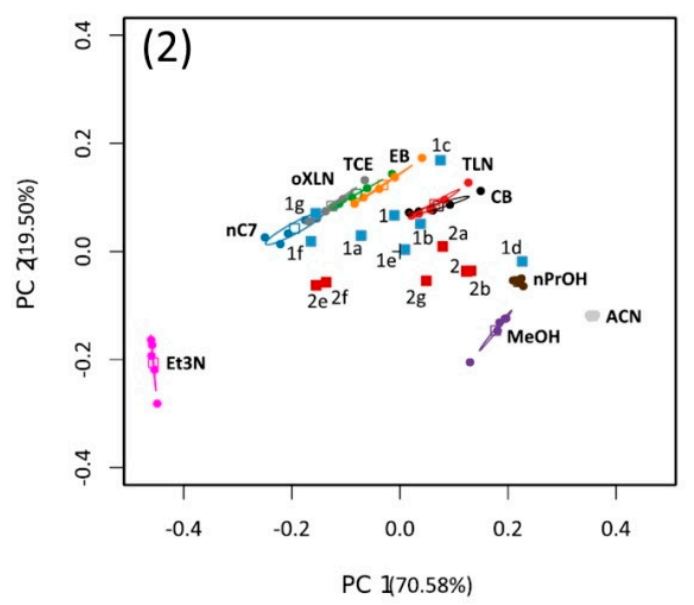

Figure 17. (1) The concept of obtaining a large set of phthalocyanine-based sensitive materials from a single starting compound by adding various axial ligands $\mathrm{L}$ to the metal ion center. (2) A PCA biplot showing the first two principle components obtained using the response data of the axially substituted TiOPc-coated QCM sensors. Loadings data are scaled to fit. Tetra- and octasubstituted TiOPcs are identified by blue or red squares. Reprinted from [54] with permission from Elsevier.

The increased affinity of fluorinated phthalocyanines for polar compounds makes them very suitable for sensors for polar DMMP and other organophosphate compounds. Eleven different $\mathrm{ZnPc}$ and NiPc with different fluorinated substitutions (Figure 18a) were used to study the sensor response to DMMP by QCM and surface acoustic wave (SAW) methods, in order to choose compounds with the best sensor response [110]. It was shown that the sensor response is influenced by the central metal, but to a much greater extent by the nature and number of substituents. For this reason, all factors must be taken into account when choosing compounds with the best sensor properties. Among the studied compounds, the best sensor response to DMMP, measured by a QCM technique, was observed for the derivatives $1 \mathrm{~b}$ and $2 \mathrm{c}$ (Figure 18b) with the calculated LOD of $0.6 \mathrm{ppm}$ and $0.8 \mathrm{ppm}$, respectively. Interestingly, the sensitivity of the same compounds to DMMP, studied by a SAW technique, was different (Figure 18c), which the authors explained by the viscoelasticity of the materials and the inhomogeneity in the sensing layers. The compound $1 \mathrm{~b}$ had also the best sensor response to DMMP, but the response value for $2 \mathrm{c}$ was less, and was comparable with other investigated phthalocyanine derivatives. In the case of $1 b$, LOD was as low as $50 \mathrm{ppb}$ both in dry and humid air. 

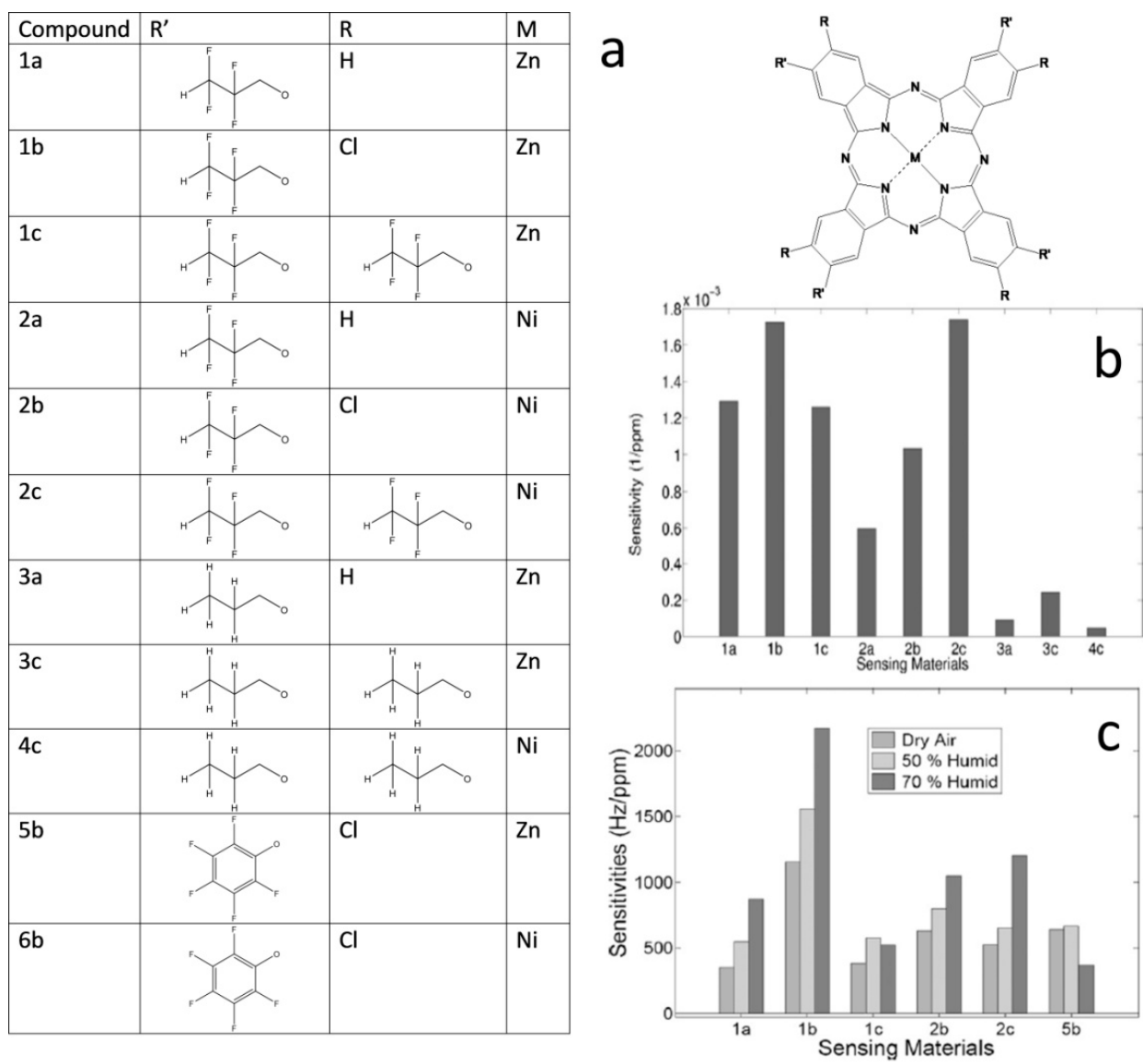

Figure 18. Chemical structures of phthalocyanines with $R$ and $R^{\prime}$ substituents (a). DMMP sensitivities of phthalocyanines having fluorinated and non-fluorinated substituents as obtained with QCM sensors in dry air (b) and SAW sensitivities (c) for the selected compounds. Adapted from [110] with permission from Elsevier.

Ahmetali et al. [111] studied relative humidity sensing performance of fluoro-substituted asymmetric zinc phthalocyanines substituted with 3-hydroxy-3-methyl-1-butynyl, ethynyl, and 4-nitrophenylethynyl (Compounds 16, Table 1) films, using quartz crystal microbalance (QCM). Results indicated that the value of sensor response and the response and recovery times strongly depended on the thickness of the sensor layer, and the best characteristics were obtained at the film thickness of $450 \mathrm{~nm}$. The most useful sensor for the determination of relative humidity was found to be the film of peripherally substituted unsymmetrical ZnPc bearing nitrophenyl group (Compound 16c, Table 1).

Thus, the use of QCM sensors based on fluorinated phthalocyanines makes it possible to detect not only oxidizing and reducing gases, but also VOCs, which play a critical role in food quality control [117], explosives detection [118], and medical diagnostics [119]. The creation of E-noses, or cross-reactive sensor arrays on the basis of fluorinated phthalocyanines, together with MPcs bearing other types of substituents, could open up broad prospects for wider use of these materials for the detection of important analytes in gas mixtures.

\section{Conclusions}

An overview of the current state of research in the field of applications of fluorosubstituted metal phthalocyanines as active layers of gas sensors was provided in this review. The literature analysis shows that both phthalocyanines with fluorine atoms directly in the aromatic rings and phthalocyanines bearing fluoroalkyl and fluoroaryl substituents are widely used for the preparation of active layers of gas sensors. In these 
compounds, fluorine demonstrates electron-withdrawing effects, molecule stability, and enhanced chemical interactions.

In most publications, fluorinated phthalocyanines are usually compared with their non-fluorinated counterparts to observe the degree of improvement in sensor properties. Perfluorination and the introduction of some fluoroalkyl and fluoroaryl groups lead to a decrease in HOMO and LUMO energy levels, facilitating electron injection. In addition, the introduction of F-substituents into the phthalocyanine aromatic rings causes an increase in charge carrier mobilities, thus improving the performance of sensing devices. Apart from this, fluorine substituents decrease the electron density of the aromatic ring and increase the oxidation potential of the MPc molecule. As a result, fluoro-substituted phthalocyanines exhibit a higher sensor response to reducing gases such as ammonia.

Thin films of $\mathrm{MPcF}_{\mathrm{x}}(\mathrm{M}=\mathrm{Cu}, \mathrm{Co}, \mathrm{Zn}, \mathrm{Pb}, \mathrm{Pd} \mathrm{VO} ; \mathrm{x}=4,16)$ derivatives have already been systematically investigated as active layers for ammonia detection. It was shown that among investigated $\mathrm{MPcF}_{\mathrm{x}}$, phthalocyanines of cobalt and zinc demonstrated the best sensing performance, with the limit of $\mathrm{NH}_{3}$ detection reaching $0.1 \mathrm{ppm}$ in the case of $\mathrm{CoPcF}_{4}$ and $\mathrm{ZnPcF}_{4}$ films. A similar tendency was also observed in the case of SPR sensors. They can be used for the selective detection of $\mathrm{NH}_{3}$ in the presence of some reducing gases and volatile organic compounds, namely carbon dioxide, acetone, dichloromethane and ethanol, and even at high humidity. These properties make $\mathrm{MPcF}_{\mathrm{x}}$ films good candidates for future applications as sensors for detecting ammonia in exhaled air, which is known to be a biomarker of renal failure in nephritis, atherosclerosis of the renal arteries, toxic lesions, and other kidney diseases.

Sensing layers of phthalocyanines bearing fluoroalkyl or fluoroaryl moieties are less investigated than $\mathrm{MPcF}_{\mathrm{x}}$, and questions about the effect of the number and the type of fluorine-containing substituents on the sensor performance have not been sufficiently answered, and may be the subject of future research, although some regularities can be noted. At the same time, the chemical versatility of substituted phthalocyanines allows the introduction of various substituents, which can allow for a wide variation in the sensitivity of compounds to analytes of different nature. Moreover, the better solubility of MPcs with fluoroalkyl or fluoroaryl substitutes compared to $\mathrm{MPcF}_{\mathrm{x}}$ derivatives provides the ability to produce inks and to use inkjet printing, which offers several advantages over other methods for the deposition of thin films. Similarly to $\mathrm{MPcF}_{\mathrm{x}}$, chemiresistive sensors based on MPcs with fluoroalkyl and fluoroaryl substituents demonstrate high sensitivity to ammonia with the detection limit up to $0.15-0.3 \mathrm{ppm}$. They were also shown to demonstrate quite good electrical response to $\mathrm{NO}_{2}$ with the detection limit of tenths of $\mathrm{ppm}$.

QCM sensors based on MPcs with fluoroalkyl and fluoroaryl substituents are good candidates for the detection of volatile organic compounds, which play a critical role in food quality control, explosives detection, and medical diagnostics. Their octasubstituted derivatives demonstrate the better sensor performance in comparison with their tetrasubstituted analogues, and they are shown to be very sensitive to dimethyl methylphosphonate aromatic hydrocarbons with a detection limit at the ppb level.

Author Contributions: Conceptualization, T.B.; methodology, T.B.; writing-original draft preparation, D.K., D.B. and T.B.; writing-review and editing, D.K., D.B. and T.B.; visualization, D.K., D.B. and T.B.; supervision, T.B. All authors have read and agreed to the published version of the manuscript.

Funding: This research was funded by the Russian Ministry of Education and Science.

Institutional Review Board Statement: Not applicable.

Informed Consent Statement: Not applicable.

Data Availability Statement: Not applicable.

Conflicts of Interest: The authors declare no conflict of interest. 


\section{References}

1. Chen, L.; Sagar, R.U.R.; Chen, J.; Liu, J.; Aslam, S.; Nosheen, F.; Anwar, T.; Hussain, N.; Hou, X.; Liang, T. Cobalt phthalocyanine as an efficient catalyst for hydrogen evolution reaction. Int. J. Hydrogen Energy 2021, 46, 19338-19346. [CrossRef]

2. Thiruppathiraja, T.; Arokiyanathan, A.L.; Aazaad, B.; Silviya, R.; Lakshmipathi, S. H, OH and COOH functionalized magnesium phthalocyanine as a catalyst for oxygen reduction reaction (ORR)-A DFT study. Int. J. Hydrogen Energy 2020, 45, 8540-8548. [CrossRef]

3. Farahmand, S.; Ghiaci, M.; Asghari, S. Oxo-vanadium (IV) phthalocyanine implanted onto the modified SBA-15 as a catalyst for direct hydroxylation of benzene to phenol in acetonitrile-water medium: A kinetic study. Chem. Eng. Sci. 2021, $232,116331$. [CrossRef]

4. Ghadari, R.; Saei, P.S.; Sabri, A.; Ghasemi, Z.; Kong, F. Enhanced phthalocyanine-sensitized solar cell efficiency via cooperation of nitrogen-doped carbon dots. J. Clean. Prod. 2020, 268, 122236. [CrossRef]

5. Ghadari, R.; Sabri, A.; Saei, P.S.; Kong, F.T.; Marques, H.M. Phthalocyanine-silver nanoparticle structures for plasmon-enhanced dye-sensitized solar cells. Sol. Energy 2020, 198, 283-294. [CrossRef]

6. Benhaliliba, M. A growth of A-Z phthalocyanine layers onto Si by thermal evaporation process to achieve organic heterojunction diodes. Optik 2020, 217, 164832. [CrossRef]

7. Raveendra Kiran, M.; Ulla, H.; Satyanarayan, M.N.; Umesh, G. Optoelectronic properties of hybrid diodes based on vanadylphthalocyanine and zinc oxide nanorods thin films. Opt. Mater. 2019, 96, 109348. [CrossRef]

8. Jiang, H.; Hu, P.; Ye, J.; Li, Y.; Li, H.; Zhang, X.; Li, R.; Dong, H.; Hu, W.; Kloc, C. Molecular Crystal Engineering: Tuning Organic Semiconductor from p-type to n-type by Adjusting Their Substitutional Symmetry. Adv. Mater. 2017, 29, 1605053. [CrossRef]

9. Shao, X.; Wang, S.; Li, X.; Su, Z.; Chen, Y.; Xiao, Y. Single component p-, ambipolar and n-type OTFTs based on fluorinated copper phthalocyanines. Dyes Pigments 2016, 132, 378-386. [CrossRef]

10. Chia, L.S.; Du, Y.H.; Palale, S.; Lee, P.S. Interaction of Copper Phthalocyanine with Nitrogen Dioxide and Ammonia Investigation Using X-ray Absorption Spectroscopy and Chemiresistive Gas Measurements. ACS Omega 2019, 4, 10388-10395. [CrossRef] [PubMed]

11. Diab, N.; Morales, D.M.; Andronescu, C.; Masoud, M.; Schuhmann, W. A sensitive and selective graphene/cobalt tetrasulfonated phthalocyanine sensor for detection of dopamine. Sens. Actuators B Chem. 2019, 285, 17-23. [CrossRef]

12. Chaabene, M.; Gassoumi, B.; Mignon, P.; Ben Chaâbane, R.; Allouche, A.R. New zinc phthalocyanine derivatives for nitrogen dioxide sensors: A theoretical optoelectronic investigation. J. Mol. Graph. Model. 2019, 88, 174-182. [CrossRef] [PubMed]

13. Zhao, Y.Y.; Chen, J.Y.; Hu, J.Q.; Zhang, L.; Lin, A.L.; Wang, R.; Zheng, B.Y.; Ke, M.R.; Li, X.; Huang, J.D. The substituted zinc(II) phthalocyanines using "sulfur bridge" as the linkages. Synthesis, red-shifted spectroscopic properties and structure-inherent targeted photodynamic activities. Dyes Pigments 2021, 189, 109270. [CrossRef]

14. Al-Raqa, S.Y.; Khezami, K.; Kaya, E.N.; Durmuş, M. A novel water soluble axially substituted silicon(IV) phthalocyanine bearing quaternized 4-(4-pyridinyl)phenol groups: Synthesis, characterization, photophysicochemical properties and BSA/DNA binding behavior. Polyhedron 2021, 194, 114937. [CrossRef]

15. Kuzmina, E.A.; Dubinina, T.V.; Tomilova, L.G. Recent advances in chemistry of phthalocyanines bearing electron-withdrawing halogen, nitro and: $\mathrm{N}$-substituted imide functional groups and prospects for their practical application. New J. Chem. 2019, 43, 9314-9327. [CrossRef]

16. Kuzmina, E.A.; Dubinina, T.V.; Vasilevsky, P.N.; Saveliev, M.S.; Gerasimenko, A.Y.; Borisova, N.E.; Tomilova, L.G. Novel octabromo-substituted lanthanide(III) phthalocyanines-Prospective compounds for nonlinear optics. Dyes Pigments 2021, 185, 108871. [CrossRef]

17. Stuzhin, P.A. Fluorinated phthalocyanine and their analogues. In Fluorine in Heterocyclic Chemistry: Volume 1: 5-Membered Heterocycles and Macrocycles; Nenajdenko, V., Ed.; Springer: Cham, Switzerland, 2014; Volume 1, pp. 621-681. ISBN 9783319043463.

18. Li, Y.; Han, X.; Li, Y.; Zhou, W.; Li, P.; Liu, R.; Lin, X.; Huang, Z.; Feng, X.; Ma, Y. Air-stable, transparent flexible ambipolar organic

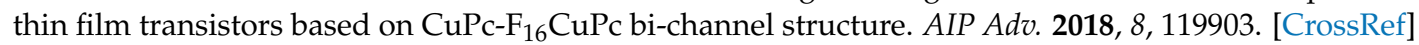

19. Wei, Z.; Xu, W.; Hu, W.; Zhu, D. Air-stable ambipolar organic field-effect transistor based on a novel bi-channel structure. J. Mater. Chem. 2008, 18, 2420-2422. [CrossRef]

20. Eguchi, K.M.; Matsushita, M.; Awaga, K. In Situ Real-Time Measurements for Ambipolar Channel Formation Processes in Organic Double-Layer Field-Effect Transistors of CuPc and F 16 CuPc. J. Phys. Chem. C 2018, 122, 26054-26060. [CrossRef]

21. Klyamer, D.; Sukhikh, A.; Gromilov, S.; Krasnov, P.; Basova, T. Fluorinated metal phthalocyanines: Interplay between fluorination degree, films orientation, and ammonia sensing properties. Sensors 2018, 18, 2141. [CrossRef]

22. Schlettwein, D.; Graaf, H.; Meyer, J.-P.; Oekermann, T.I.; Jaeger, N. Molecular Interactions in Thin Films of Hexadecafluorophthalocyaninatozinc $\left(\mathrm{F}_{16} \mathrm{PcZn}\right)$ as Compared to Islands of $\mathrm{N}, \mathrm{N}^{\prime}$-Dimethylperylene-3,4,9,10-biscarboximide (MePTCDI). J. Phys. Chem. B 1999, 103, 3078-3086. [CrossRef]

23. Zagal, J.H.; Griveau, S.; Silva, J.F.; Nyokong, T.; Bedioui, F. Metallophthalocyanine-based molecular materials as catalysts for electrochemical reactions. Coord. Chem. Rev. 2010, 254, 2755-2791. [CrossRef]

24. Valli, L. Phthalocyanine-based Langmuir-Blodgett films as chemical sensors. Adv. Colloid Interface Sci. 2005, 116, 13-44. [CrossRef] [PubMed]

25. Bouvet, M.; Gaudillat, P.; Suisse, J.M. Phthalocyanine-based hybrid materials for chemosensing. J. Porphyr. Phthalocyanines 2013, 17, 913-919. [CrossRef] 
26. Rodriguez-Méndez, M.L.; Gay, M.; De Saja, J.A. New insights into sensors based on radical bisphthalocyanines. J. Porphyr. Phthalocyanines 2009, 13, 1159-1167. [CrossRef]

27. Nesakumar, N.; Berchmans, S.; Alwarappan, S. Chemically modified carbon based electrodes for the detection of reduced glutathione. Sens. Actuators B Chem. 2018, 264, 448-466. [CrossRef]

28. Moraes, F.C.; Cabral, M.F.; Machado, S.A.S.; Mascaro, L.H. Electrocatalytic behavior of glassy carbon electrodes modified with multiwalled carbon nanotubes and cobalt phthalocyanine for selective analysis of dopamine in presence of ascorbic acid. Electroanalysis 2008, 20, 851-857. [CrossRef]

29. Bhupathiraju, N.V.S.D.K.; Rizvi, W.; Batteas, J.D.; Drain, C.M. Fluorinated porphyrinoids as efficient platforms for new photonic materials, sensors, and therapeutics. Org. Biomol. Chem. 2016, 14, 389-408. [CrossRef] [PubMed]

30. Casa, S.; Henary, M. Synthesis and Applications of Selected Fluorine-Containing Fluorophores. Molecules 2021, 26, 1160. [CrossRef] [PubMed]

31. Carrión, E.N.; Loas, A.; Patel, H.H.; Pelmuş, M.; Ramji, K.; Gorun, S.M. Fluoroalkyl phthalocyanines: Bioinspired catalytic materials. J. Porphyr. Phthalocyanines 2018, 22, 371-397. [CrossRef]

32. Klyamer, D.D.; Sukhikh, A.S.; Trubin, S.V.; Gromilov, S.A.; Morozova, N.B.; Basova, T.V.; Hassan, A.K. Tetrafluorosubstituted Metal Phthalocyanines: Interplay between Saturated Vapor Pressure and Crystal Structure. Cryst. Growth Des. 2020, 20, 1016-1024. [CrossRef]

33. Harbeck, M.; Taşaltın, C.; Gürol, I.; Musluoğlu, E.; Ahsen, V.; Öztürk, Z.Z. Preferential sorption of polar compounds by fluoroalkyloxy substituted phthalocyanines for the use in sorption based gas sensors. Sens. Actuators B Chem. 2010, 150, 616-624. [CrossRef]

34. Jiang, H.; Ye, J.; Hu, P.; Wei, F.; Du, K.; Wang, N.; Ba, T.; Feng, S.; Kloc, C. Fluorination of metal phthalocyanines: Single-crystal growth, efficient N-channel organic field-effect transistors, and structure-property relationships. Sci. Rep. 2014, 4, 7573. [CrossRef] [PubMed]

35. Hong, S.M.; Mutyala, A.K.; Cha, M.J.; Seo, J.H.; Kang, Y.A.; Park, J.S. Preparation of Alkylated and Perfluorinated ZnPc-modified Carbon Nanotubes and their Application as Conductive Fillers for Poly(vinylidene fluoride) Composite Dielectrics. Bull. Korean Chem. Soc. 2017, 38, 1190-1195. [CrossRef]

36. Skonieczny, R.; Popielarski, P.; Bała, W.; Fabisiak, K.; Paprocki, K.; Jancelewicz, M.; Kowalska, M.; Szybowicz, M. Effect of annealing temperature on optical and electrical properties of metallophthalocyanine thin films deposited on silicon substrate. Mater. Sci. Pol. 2016, 34, 676-683. [CrossRef]

37. Schuster, B.E.; Basova, T.V.; Plyashkevich, V.A.; Peisert, H.; Chassé, T. Effects of temperature on structural and morphological features of CoPc and CoPcF16 thin films. Thin Solid Films 2010, 518, 7161-7166. [CrossRef]

38. Cook, M.J.; Chambrier, I. Phthalocyanine Thin Films: Deposition and Structural Studies. In The Porphyrin Handbook; Academic Press: Cambridge, MA, USA, 2003; pp. 37-127, ISBN 9780080923918.

39. Basova, T.V.; Kiselev, V.G.; Dubkov, I.S.; Latteyer, F.; Gromilov, S.A.; Peisert, H.; Chassè, T. Optical spectroscopy and XRD study of molecular orientation, polymorphism, and phase transitions in fluorinated vanadyl phthalocyanine thin films. J. Phys. Chem. C 2013, 117, 7097-7106. [CrossRef]

40. Wright, J. Gas adsorption on phthalocyanines and its effects on electrical properties. Prog. Surf. Sci. 1989, 31, 1-60. [CrossRef]

41. Schön, J.H.; Bao, Z. Influence of disorder on the electron transport properties in fluorinated copper-phthalocyanine thin films. J. Appl. Phys. 2001, 89, 3526-3528. [CrossRef]

42. Ye, R.; Baba, M.; Suzuki, K.; Mori, K. Improved performance of fluorinated copper phthalocyanine thin film transistors using an organic p-n junction: Effect of copper phthalocyanine film thickness. Thin Solid Films 2009, 517, 3001-3004. [CrossRef]

43. Ye, R.; Baba, M.; Ohishi, Y.; Mori, K.; Suzuki, K. On the correlation between morphology and electronic properties of fluorinated copper phthalocyanine $\left(\mathrm{F}_{16} \mathrm{CuPc}\right)$ thin films. Mol. Cryst. Liq. Cryst. 2006, 444, 203-210. [CrossRef]

44. Ballirano, P.; Caminiti, R.; Ercolani, C.; Maras, A.; Orrù, M.A. X-ray powder diffraction structure reinvestigation of the $\alpha$ and $\beta$ forms of cobalt phthalocyanine and kinetics of the $\alpha \rightarrow \beta$ phase transition. J. Am. Chem. Soc. 1998, 120, 12798-12807. [CrossRef]

45. Vergnat, C.; Landais, V.; Legrand, J.F.; Brinkmann, M. Orienting semiconducting nanocrystals on nanostructured polycarbonate substrates: Impact of substrate temperature on polymorphism and in-plane orientation. Macromolecules 2011, 44, 3817-3827. [CrossRef]

46. Klyamer, D.D.; Sukhikh, A.S.; Gromilov, S.A.; Kruchinin, V.N.; Spesivtsev, E.V.; Hassan, A.K.; Basova, T.V. Influence of fluorosubstitution on the structure of zinc phthalocyanine thin films. Macroheterocycles 2018, 11, 304-311. [CrossRef]

47. Pandey, P.A.A.; Rochford, L.S.; Keeble, D.P.; Rourke, J.S.; Jones, T.; Beanland, R.R.; Wilson, N. Resolving the Nanoscale Morphology and Crystallographic Structure of Molecular Thin Films: $\mathrm{F}_{16} \mathrm{CuPc}$ on Graphene Oxide. Chem. Mater. 2012, 24, 1365-1370. [CrossRef]

48. Yoon, S.M.; Song, H.J.; Hwang, I.C.; Kim, K.S.; Choi, H.C. Single crystal structure of copper hexadecafluorophthalocyanine ( $\mathrm{F}_{16} \mathrm{CuPc}$ ) ribbon. Chem. Commun. 2010, 46, 231-233. [CrossRef] [PubMed]

49. Kuprikova, N.M.; Klyamer, D.D.; Sukhikh, A.S.; Krasnov, P.O.; Mrsic, I.; Basova, T.V. Fluorosubstituted lead phthalocyanines: Crystal structure, spectral and sensing properties. Dyes Pigments 2020, 173, 107939. [CrossRef]

50. Klyamer, D.; Sukhikh, A.; Nikolaeva, N.; Morozova, N.; Basova, T. Vanadyl phthalocyanine films and their hybrid structures with Pd nanoparticles: Structure and sensing properties. Sensors 2020, 20, 1893. [CrossRef] [PubMed] 
51. Kaya, E.N.; Şenocak, A.; Klyamer, D.D.; Demirbaş, E.; Basova, T.V.; Durmuş, M. Ammonia sensing performance of thin films of cobalt(II) phthalocyanine bearing fluorinated substituents. J. Mater. Sci. Mater. Electron. 2019, 30, 7543-7551. [CrossRef]

52. Duan, X.; Zhang, Y.; Wang, H.; Dai, F.; Yang, G.; Chen, Y. A phthalocyanine sensor array based on sensitivity and current changes for highly sensitive identification of three toxic gases at ppb levels. New J. Chem. 2020, 44, 13240-13248. [CrossRef]

53. Hu, J.; Sun, Y.; Xue, Y.; Zhang, M.; Li, P.; Lian, K.; Zhuiykov, S.; Zhang, W.; Chen, Y. Highly sensitive and ultra-fast gas sensor based on $\mathrm{CeO}_{2}$-loaded $\mathrm{In}_{2} \mathrm{O}_{3}$ hollow spheres for ppb-level hydrogen detection. Sens. Actuators B Chem. 2018, 257, 469-476. [CrossRef]

54. Şen, Z.; Tarakci, D.K.; Gürol, I.; Ahsen, V.; Harbeck, M. Governing the sorption and sensing properties of titanium phthalocyanines by means of axial ligands. Sens. Actuators B Chem. 2016, 229, 581-586. [CrossRef]

55. Dong, Z.; Kong, X.; Wu, Y.; Zhang, J.; Chen, Y. High-sensitive room-temperature NO2 sensor based on a soluble n-type phthalocyanine semiconductor. Inorg. Chem. Commun. 2017, 77, 18-22. [CrossRef]

56. Basova, T.V.; Hassan, A.; Krasnov, P.O.; Gürol, I.; Ahsen, V. Trimethylamine sorption into thin layers of fluoroalkyloxy and alkyloxy substituted phthalocyanines: Optical detection and DFT calculations. Sens. Actuators B Chem. 2015, 216, 204-211. [CrossRef]

57. Sun, Q.; Feng, W.; Yang, P.; You, G.; Chen, Y. Highly selective room-temperature NO2 sensors based on a fluoroalkoxy-substituted phthalocyanine. New J. Chem. 2018, 42, 6713-6718. [CrossRef]

58. Wang, X.; Wang, H.; Ding, X.; Wang, X.; Li, X.; Chen, Y. High-performance room-temperature $\mathrm{NO}_{2}$ sensors based on microstructures self-assembled from n-type phthalocyanines: Effect of fluorine-hydrogen bonding and metal-ligand coordination on morphology and sensing performance. Org. Electron. 2017, 50, 389-396. [CrossRef]

59. Liu, Q.; Gao, L.; Su, X.; Zhou, F.; Duan, G. Interfacial self-assembly of CoPc thin films with their high sensing use as $\mathrm{NO}_{2}$ sensors. Mater. Chem. Phys. 2019, 234, 94-101. [CrossRef]

60. Liu, C.J.; Peng, C.H.; Ju, Y.H.; Hsieh, J.C. Titanyl phthalocyanine gas sensor for $\mathrm{NO}_{2}$ detection. Sens. Actuators B Chem. 1998, 52, 264-269. [CrossRef]

61. Nemakal, M.; Aralekallu, S.; Mohammed, I.; Pari, M.; Venugopala Reddy, K.; Sannegowda, L.K. Nanomolar detection of 4-aminophenol using amperometric sensor based on a novel phthalocyanine. Electrochim. Acta 2019, 318, 342-353. [CrossRef]

62. Klyamer, D.D.; Sukhikh, A.S.; Krasnov, P.O.; Gromilov, S.A.; Morozova, N.B.; Basova, T.V. Thin films of tetrafluorosubstituted cobalt phthalocyanine: Structure and sensor properties. Appl. Surf. Sci. 2016, 372, 79-86. [CrossRef]

63. Sharma, A.K.; Mahajan, A.; Saini, R.; Bedi, R.K.; Kumar, S.; Debnath, A.K.; Aswal, D.K. Reversible and fast responding ppb level Cl 2 sensor based on noncovalent modified carbon nanotubes with Hexadecafluorinated copper phthalocyanine. Sens. Actuators B Chem. 2018, 255, 87-99. [CrossRef]

64. Sharma, A.K.; Mahajan, A.; Bedi, R.K.; Kumar, S.; Debnath, A.K.; Aswal, D.K. Non-covalently anchored multi-walled carbon nanotubes with hexa-decafluorinated zinc phthalocyanine as ppb level chemiresistive chlorine sensor. Appl. Surf. Sci. 2018, 427, 202-209. [CrossRef]

65. Zhang, B.; Tai, H.L.; Xie, G.Z.; Li, X.; Zhang, H.N. The investigation of a new $\mathrm{NO}_{2}$ OTFT sensor based on heterojunction $\mathrm{F}_{16} \mathrm{CuPc} / \mathrm{CuPc}$ thin films. Adv. Mater. Res. 2013, 721, 159-163. [CrossRef]

66. Nikolaeva, N.S.; Klyamer, D.D.; Zharkov, S.M.; Tsygankova, A.R.; Sukhikh, A.S.; Morozova, N.B.; Basova, T.V. Heterostructures based on Pd-Au nanoparticles and cobalt phthalocyanine for hydrogen chemiresistive sensors. Int. J. Hydrogen Energy 2021, 46, 19682-19692. [CrossRef]

67. Sukhikh, A.S.; Klyamer, D.D.; Parkhomenko, R.G.; Krasnov, P.O.; Gromilov, S.A.; Hassan, A.K.; Basova, T.V. Effect of fluorosubstitution on the structure of single crystals, thin films and spectral properties of palladium phthalocyanines. Dyes Pigments 2018, 149, 348-355. [CrossRef]

68. Parkhomenko, R.G.; Sukhikh, A.S.; Klyamer, D.D.; Krasnov, P.O.; Gromilov, S.; Kadem, B.; Hassan, A.K.; Basova, T.V. Thin Films of Unsubstituted and Fluorinated Palladium Phthalocyanines: Structure and Sensor Response toward Ammonia and Hydrogen. J. Phys. Chem. C 2017, 121, 1200-1209. [CrossRef]

69. Yang, R.D.; Park, J.; Colesniuc, C.N.; Schuller, I.K.; Royer, J.E.; Trogler, W.C.; Kummel, A.C. Analyte chemisorption and sensing on n- and p-channel copper phthalocyanine thin-film transistors. J. Chem. Phys. 2009, 130, 164703. [CrossRef]

70. Zhang, C.; Chen, P.; Hu, W. Organic field-effect transistor-based gas sensors. Chem. Soc. Rev. 2015, 44, 2087-2107. [CrossRef] [PubMed]

71. Liu, Y.; Yang, D.; Wang, C. Molecular Interface Effect of Heterogeneous Molecular Junctions Consisting of Nonfluorinated and Fluorinated Phthalocyanines. J. Phys. Chem. B 2006, 110, 20789-20793. [CrossRef]

72. Ouedraogo, S.; Ouedraogo, S.; Meunier-Prest, R.; Kumar, A.; Bayo-Bangoura, M.; Bouvet, M. Modulating the Electrical Properties of Organic Heterojunction Devices Based on Phthalocyanines for Ambipolar Sensors. ACS Sens. 2020, 5, 1849-1857. [CrossRef]

73. Ye, R.; Ohta, K.; Baba, M. In-situ study of pn-heterojunction interface states in organic thin film transistors. Thin Solid Films 2014, 554, 137-140. [CrossRef]

74. Parra, V.; Brunet, J.; Pauly, A.; Bouvet, M. Molecular semiconductor-doped insulator (MSDI) heterojunctions: An alternative transducer for gas chemosensing. Analyst 2009, 134, 1776-1778. [CrossRef]

75. Kumar, A.; Meunier-Prest, R.; Bouvet, M. Organic heterojunction devices based on phthalocyanines: A new approach to gas chemosensing. Sensors 2020, 20, 4700. [CrossRef] [PubMed] 
76. Schöllhorn, B.; Germain, J.P.; Pauly, A.; Maleysson, C.; Blanc, J.P. Influence of peripheral electron-withdrawing substituents on the conductivity of zinc phthalocyanine in the presence of gases. Part 1: Reducing gases. Thin Solid Films 1998, 326, 245-250. [CrossRef]

77. Ma, X.; Chen, H.; Shi, M.; Wu, G.; Wang, M.; Huang, J. High gas-sensitivity and selectivity of fluorinated zinc phthalocyanine film to some non-oxidizing gases at room temperature. Thin Solid Films 2005, 489, 257-261. [CrossRef]

78. Bengasi, G.; Meunier-Prest, R.; Baba, K.; Kumar, A.; Pellegrino, A.L.; Boscher, N.D.; Bouvet, M. Molecular Engineering of Porphyrin-Tapes/Phthalocyanine Heterojunctions for a Highly Sensitive Ammonia Sensor. Adv. Electron. Mater. 2020, 6, 1-12. [CrossRef]

79. Bouvet, M.; Gaudillat, P.; Kumar, A.; Sauerwald, T.; Schüler, M.; Schütze, A.; Suisse, J.M. Revisiting the electronic properties of Molecular Semiconductor-Doped Insulator (MSDI) heterojunctions through impedance and chemosensing studies. Org. Electron. 2015, 26, 345-354. [CrossRef]

80. Mateos, M.; Meunier-Prest, R.; Suisse, J.M.; Bouvet, M. Modulation of the organic heterojunction behavior, from electrografting to enhanced sensing properties. Sens. Actuators B Chem. 2019, 299, 126968. [CrossRef]

81. Wang, X.; Ji, S.; Wang, H.; Yan, D. Highly sensitive gas sensor enhanced by tuning the surface potential. Org. Electron. 2011, 12, 2230-2235. [CrossRef]

82. Zhao, S.; Kong, X.; Wang, X.; Li, X.; Yang, G.; Chen, Y. Fine-tuning intermolecular and intramolecular interactions to build the films of tris(phthalocyaninato) rare earth complexes and their comparative performances in ambipolar gas sensing. IEEE Trans. Electron Devices 2019, 66, 1930-1936. [CrossRef]

83. Kumar, S.; Sharma, A.K.; Sohal, M.K.; Sharma, D.P.; Debnath, A.K.; Aswal, D.K.; Mahajan, A. Room temperature highly sensitive chlorine sensor based on reduced graphene oxide anchored with substituted copper phthalocyanine. Sens. Actuators B Chem. 2021, 327, 128925. [CrossRef]

84. Sharma, A.K.; Mahajan, A.; Bedi, R.K.; Kumar, S.; Debnath, A.K.; Aswal, D.K. CNTs based improved chlorine sensor from non-covalently anchored multi-walled carbon nanotubes with hexa-decafluorinated cobalt phthalocyanines. RSC Adv. 2017, 7, 49675-49683. [CrossRef]

85. Sharma, A.K.; Mahajan, A.; Kumar, S.; Debnath, A.K.; Aswal, D.K. Tailoring of the chlorine sensing properties of substituted metal phthalocyanines non-covalently anchored on single-walled carbon nanotubes. RSC Adv. 2018, 8, 32719-32730. [CrossRef]

86. Bonegardt, D.; Klyamer, D.; Köksoy, B.; Durmuş, M.; Basova, T. Hybrid materials of carbon nanotubes with fluoroalkyl-and alkyl-substituted zinc phthalocyanines. J. Mater. Sci. Mater. Electron. 2020, 31, 11021-11028. [CrossRef]

87. Hesse, K.; Schlettwein, D. Spectroelectrochemical investigations on the reduction of thin films of hexadecafluorophthalocyaninatozinc $\left(\mathrm{F}_{16} \mathrm{PcZn}\right)$. J. Electroanal. Chem. 1999, 476, 148-158. [CrossRef]

88. Engel, M.K. Single-Crystal Structures of Phthalocyanine Complexes and Related Macrocycles. In The Porphyrin Handbook: Phthalocyanines: Structural Characterization; Elsevier: Amsterdam, The Netherlands, 2012; Volume 20, pp. 122-142.

89. Brinkmann, H.; Kelting, C.; Makarov, S.; Tsaryova, O.; Schnurpfeil, G.; Wöhrle, D.; Schlettwein, D. Fluorinated phthalocyanines as molecular semiconductor thin films. Phys. Status Solidi Appl. Mater. Sci. 2008, 205, 409-420. [CrossRef]

90. Schlettwein, D.; Hesse, K.; Gruhn, N.E.; Lee, P.A.; Nebesny, K.W.; Armstrong, N.R. Electronic Energy Levels in Individual Molecules, Thin Films, and Organic Heterojunctions of Substituted Phthalocyanines. J. Phys. Chem. B 2001, 105, 4791-4800. [CrossRef]

91. Barsan, N.; Simion, C.; Heine, T.; Pokhrel, S.; Weimar, U. Modeling of sensing and transduction for p-type semiconducting metal oxide based gas sensors. J. Electroceram. 2010, 25, 11-19. [CrossRef]

92. Kim, H.J.; Lee, J.H. Highly sensitive and selective gas sensors using p-type oxide semiconductors: Overview. Sens. Actuators $B$ Chem. 2014, 192, 607-627. [CrossRef]

93. Kerp, H.R.; Westerduin, K.T.; van Veen, A.T.; van Faassen, E.E. Quantification and effects of molecular oxygen and water in zinc phthalocyanine layers. J. Mater. Res. 2001, 16, 503-511. [CrossRef]

94. de Haan, A.; Debliquy, M.; Decroly, A. Influence of atmospheric pollutants on the conductance of phthalocyanine films. Sens. Actuators B Chem. 1999, 57, 69-74. [CrossRef]

95. Gould, R.D. Structure and electrical conduction properties of phthalocyanine thin films. Coord. Chem. Rev. 1996, 156, 237-274. [CrossRef]

96. Basova, T.V.; Mikhaleva, N.S.; Hassan, A.K.; Kiselev, V.G. Thin films of fluorinated 3d-metal phthalocyanines as chemical sensors of ammonia: An optical spectroscopy study. Sens. Actuators B Chem. 2016, 227, 634-642. [CrossRef]

97. Xiong, H.; Liu, B.; Zhang, H.; Qin, J. Theoretical insight into two-dimensional M-Pc monolayer as an excellent material for formaldehyde and phosgene sensing. Appl. Surf. Sci. 2021, 543, 148805. [CrossRef]

98. Soury, R.; Chaabene, M.; Jabli, M.; Saleh, T.A.; Ben Chaabane, R.; Saint-Aman, E.; Loiseau, F.; Philouze, C.; Allouche, A.R.; Nasri, H. Meso-tetrakis(3,4,5-trimethoxyphenyl)porphyrin derivatives: Synthesis, spectroscopic characterizations and adsorption of $\mathrm{NO}_{2}$. Chem. Eng. J. 2019, 375, 122005. [CrossRef]

99. Rana, M.K.; Sinha, M.; Panda, S. Gas sensing behavior of metal-phthalocyanines: Effects of electronic structure on sensitivity. Chem. Phys. 2018, 513, 23-34. [CrossRef]

100. Saini, R.; Mahajan, A.; Bedi, R.K.; Aswal, D.K.; Debnath, A.K. Room temperature ppb level $\mathrm{Cl}_{2}$ detection and sensing mechanism of highly selective and sensitive phthalocyanine nanowires. Sens. Actuators B Chem. 2014, 203, 17-24. [CrossRef] 
101. Kim, H.; Meihui, Z.; Battaglini, N.; Lang, P.; Horowitz, G. Large enhancement of hole injection in pentacene by modification of gold with conjugated self-assembled monolayers. Org. Electron. 2013, 14, 2108-2113. [CrossRef]

102. Bouvet, M.; Parra, V.; Suisse, J.M. Molecular semiconductor-doped insulator (MSDI) heterojunctions as new transducers for chemical sensors. EPJ Appl. Phys. 2011, 56, 34103. [CrossRef]

103. Timmer, B.; Olthuis, W.; Van Den Berg, A. Ammonia sensors and their applications-A review. Sens. Actuators B Chem. 2005, 107, 666-677. [CrossRef]

104. Kim, K.-H.; Jahan, S.A.; Kabir, E. A review of breath analysis for diagnosis of human health. TrAC Trends Anal. Chem. 2012, 33, 1-8. [CrossRef]

105. Basova, T.V.; Polyakov, M.S. Hybrid materials based on carbon nanotubes and polyaromatic molecules: Methods of functionalization and sensor properties. Macroheterocycles 2020, 13, 91-112. [CrossRef]

106. Basova, T.V.; Ray, A.K. Review-Hybrid Materials Based on Phthalocyanines and Metal Nanoparticles for Chemiresistive and Electrochemical Sensors: A Mini-Review. ECS J. Solid State Sci. Technol. 2020, 9, 061001. [CrossRef]

107. Basova, T.V.; Hassan, A. Ammonia sorption studies into thin layers of hexadecafluorinated cobalt phthalocyanine using optical techniques. J. Porphyr. Phthalocyanines 2013, 17, 934-940. [CrossRef]

108. Kumar, A.; Brunet, J.; Varenne, C.; Ndiaye, A.; Pauly, A. Phthalocyanines based QCM sensors for aromatic hydrocarbons monitoring: Role of metal atoms and substituents on response to toluene. Sens. Actuators B Chem. 2016, 230, 320-329. [CrossRef]

109. Harbeck, M.; Erbahar, D.D.; Gürol, I.; Musluolu, E.; Ahsen, V.; Öztürk, Z.Z. Phthalocyanines as sensitive coatings for QCM sensors: Comparison of gas and liquid sensing properties. Sens. Actuators B Chem. 2011, 155, 298-303. [CrossRef]

110. Tasaltin, C.; Gurol, I.; Harbeck, M.; Musluoglu, E.; Ahsen, V.; Ozturk, Z.Z. Synthesis and DMMP sensing properties of fluoroalkyloxy and fluoroaryloxy substituted phthalocyanines in acoustic sensors. Sens. Actuators B Chem. 2010, 150, 781-787. [CrossRef]

111. Ahmetali, E.; Karaoğlu, H.P.; Urfa, Y.; Altındal, A.; Koçak, M.B. A series of asymmetric zinc (II) phthalocyanines containing fluoro and alkynyl groups: Synthesis and examination of humidity sensing performance by using QCM based sensor. Mater. Chem. Phys. 2020, 254, 123477. [CrossRef]

112. Arwin, H.; Poksinski, M.; Johansen, K. Total internal reflection ellipsometry: Principles and applications. Appl. Opt. 2004, 43, 3028-3036. [CrossRef] [PubMed]

113. Basova, T.; Hassan, A.; Yuksel, F.; Gürek, A.G.; Ahsen, V. Optical detection of pentachlorophenol in water using thin films of octa-tosylamido substituted zinc phthalocyanine. Sens. Actuators B Chem. 2010, 150, 523-528. [CrossRef]

114. Nabok, A.; Tsargorodskaya, A. The method of total internal reflection ellipsometry for thin film characterisation and sensing. Thin Solid Films 2008, 516, 8993-9001. [CrossRef]

115. Tong, W.Y.B.; Djurišić, A.H.; Xie, M.C.M.; Ng, A.Y.; Cheung, K.K.; Chan, W.H.; Leung, Y.W.; Lin, H.; Gwo, S. Metal Phthalocyanine Nanoribbons and Nanowires. J. Phys. Chem. B 2006, 110, 17406-17413. [CrossRef] [PubMed]

116. Ballantine, D.S., Jr.; White, R.M.; Martin, S.J.; Ricco, A.J.; Zellers, E.T.; Frye, G.C.; Wohltjen, H. Acoustic Wave Sens.: Theory, Design and Physico-Chemical Applications, 1st ed.; Levy, M., Stern, R., Eds.; Academic Press: New York, NY, USA, 1997.

117. Toniolo, R.; Pizzariello, A.; Dossi, N.; Lorenzon, S.; Abollino, O.; Bontempelli, G. Room temperature ionic liquids as useful overlayers for estimating food quality from their odor analysis by quartz crystal microbalance measurements. Anal. Chem. 2013, 85, 7241-7247. [CrossRef] [PubMed]

118. Schnorr, J.M.; Van Der Zwaag, D.; Walish, J.J.; Weizmann, Y.; Swager, T.M. Sensory arrays of covalently functionalized singlewalled carbon nanotubes for explosive detection. Adv. Funct. Mater. 2013, 23, 5285-5291. [CrossRef]

119. Queralto, N.; Berliner, A.N.; Goldsmith, B.; Martino, R.; Rhodes, P.; Lim, S.H. Detecting cancer by breath volatile organic compound analysis: A review of array-based sensors. J. Breath Res. 2014, 8, 027112. [CrossRef] [PubMed] 